Resenhas

\title{
Sexualidades, nacionalidades e escolarização
}

\author{
Sexualidades e institución \\ escolar
}

EPSTEIN, D.; Johnson, R.

Madrid: Paideia; Ed. Morata, 2000. 232 p.

O que diferencia um livro de tantos outros que lemos e nos leva a nominá-lo como um livro especial? Essa pergunta talvez não tenha sentido quando pensamos nas leituras que fazemos com um prazer "que se constrói aos poucos, à medida que se liga a palavra à frase, ao que é dito", leituras nas quais a história ou o conteúdo, em si, quase que passam para o segundo plano, já que passa a importar muito mais "a maneira como esse narrado vai sendo desenvolvido, num crescendo, tomando o leitor por inteiro, prazer desfrutado pouco a pouco até o prazer final, supremo deleite que se sente ao fechar o livro e querer mais..."

Mas faz todo o sentido tentar responder a isso quando se trata de resenhar um livro, exatamente porque temos, então, de fazer uma análise e uma indicação -empreendimentos que envolvem refletir sobre e narrar a nossa própria experiência de leitor ou leitora. Corremos alguns riscos nesse processo porque o modo como o fazemos atravessa e demarca outras relações, ainda inscritas no futuro, com o texto em pauta. Pode-se argumentar que essa é, exatamente, a finalidade de uma resenha e, portanto, a atribuição do/a resenhista, de forma que resolvi correr esses riscos pela primeira vez, para falar de um livro que considero especial: Schooling Sexualities, o livro de Debbie Epstein e Richard Johnson, editado pela Open University Press em
1998 e que foi publicado em espanhol no ano passado (2000), por iniciativa da Fundación Paideia, no âmbito da Colección Educación Crítica, dirigida por Jurjo Torres Santomé.

Não foi propriamente pelo tipo de prazer acima referido, mas como doutoranda em fase final de curso que fiz minha primeira leitura deste livro de Epstein e Johnson, há quase três anos. Estava envolvida com a escrita de minha tese e essa leitura me foi apontada como um "exemplo" de pesquisa pós-estruturalista, na qual a construção de um referencial teóricometodológico complexo se fazia por dentro da análise empírica, numa investigação que envolvia procedimentos e dados extraídos de fontes de natureza e amplitude bastante diversas. E a autora e o autor faziam isso utilizando um estilo de escrita que, com essas características (ou apesar delas), conseguia reunir um (para mim) conjunto expressivo de qualidades: consistência, acessibilidade, clareza, simplicidade e rigor.

Naquele momento, portanto, não me aproximei do livro em função do tema nele discutido, ou buscando a "aprendizagem" dos referenciais teóricos e dos conceitos-chave ali adotados. O que eu buscava, com a leitura, era visualizar um jeito de analisar e articular dados e conceitos e de narrar esse processo de pesquisar. Um jeito que envolvesse: operar com conceitos mais do que discorrer sobre eles; possibilidades de fazer leituras significativas de aspectos naturalizados ou banalizados do cotidiano; construir um texto que expressasse a conflitualidade e multidimensionalidade do social e da cultura, explorando os efeitos da articulação de gênero com outros marcadores sociais tais como sexualidade e nacionalidade; compor uma análise na qual se conectassem, de forma visível, o olhar "interessado" reivindicado pelos Estudos Feministas e Culturais com os efeitos da virada lingüística, operada pelo pósestruturalismo de Foucault e Derrida. 
Não era pouca coisa que eu desejava saberxencontrar ali! No entanto, encontrei muito de tudo isso nesse livro, naquela ocasião. Isso me salta aos olhos cada vez que me deparo com a quantidade de marcações coloridas e com o teor das anotações com as quais enchi as margens e o corpo do texto nessa primeira leitura e sempre que revejo o texto com que narro a trajetória teórico-analítica que empreendi por dentro de minha própria investigação².

Essa é, então, uma das importantes razões pelas quais recomendo hoje, já como professora de dois programas de pós-graduação na UFRGS, a leitura do livro a estudantes e a minhas/meus orientandas/os, quando estas/es se deparam com o desafio de elaborar seus projetos e dissertações ou teses dentro destas abordagens teórico-metodológicas. O livro pode, efetivamente, ser explorado como um bom exemplo de pesquisa nestes campos teóricos. Explorá-lo sob esta ótica, no entanto, exige do leitor ou da leitora pesquisadora uma certa intimidade com teorizações feministas e culturais contemporâneas e com a obra de Michel Foucault. Exatamente porque opera com estes referenciais teóricos para analisar uma problemática específica, sem a pretensão de discuti-los exaustivamente, o texto de Epstein e Johnson não deve ser buscado com o objetivo de introduzir-se nestes campos de estudo.

Mas o livro pode e deve ser lido ainda por outras razões, sobretudo por aquelas e aqueles que tratam de discutir e problematizar as complexas e conflituosas relações que se estabelecem entre sexualidade, culturas nacionais e instituição escolar nas sociedades ocidentais contemporâneas.

Egressos do Departamento de Estudos Culturais de Birminghan Inglaterra - onde este campo de estudos de estruturou e consolidou a partir dos anos 70, Debbie Epstein e Richard Johnson são estudiosos culturais e feministas que contabilizam uma extensa produção intelectual. Debbie trabalha como professora e orientadora na Faculdade de Educação da Universidade de Londres e Richard Johnson na Universidade Trent de Nothingham. Em consonância com as perspectivas teóricas e políticas que assumem, a autora e o autor se inscrevem dentro de sua investigação e, ao fazê-lo, colocam em plano crítico processos particularmente significativos de sua vida e de sua formação em relação à sexualidade, gênero, raça e nacionalidade. Para Debbie

la marginación y la estigmatización de determinados grupos há sido tema de sus estudios desde donde le alcanza el recuerdo. Su origen y educación judios, de sudafricana opuesta al segregacionismo, partícipe de una tradición de socialismo judio, fueran la clave de la temprana formación de su identidad. [...] quando se declaró lesbiana publicamente [...] se hizo, tal vez, inevitable que más pronto o más tarde su trabajo se centrara en los temas de sexualidad y escuela (p. 20).

Já Richard Johnson refere que suas diversas identidades não marcadas (homem branco, de classe média e heterossexual) contribuíram para que a sexualidade não se constituísse como uma

clave tan evidente de su vida personal. [..] las preocupaciones por la sexualidad y la escuela surgieron en parte de las experiencias de sus intimos amigos homossexuales y lesbianas. La influencia de sus amigos y colegas feministas le llevaron también a hacerse preguntas sobre la heterosexualidad (p. 20).

É, pois, acerca das implicações das políticas educacionais inglesas (fortemente marcadas pelo tatcherismo, pelo neoliberalismo e pelo novo trabalhismo dos anos 90) e de sua veiculação e discussão na mídia, sobre o processo de escolarização e sobre a produção de identidades sexuais e de gênero que se efetiva neste espaço, que trata o livro. Fundamentalmente, a autora e o autor procuram explorar as relações entre sexualidades e escola, nacionalidades e sexualidades e nacionalidades e escola, e a discussão acerca destas relações é apresentada, no livro, em duas grandes partes.

A primeira parte, intitulada Las sexualidades en el ámbito público, analisa os processos pelos quais a política, o governo formal e os meios de comunicação produzem um determinado tipo de "público nacional" que parece e pretende ser universal. Nesta parte se explora e se exercita, portanto, de forma ampla e consistente, uma das grandes contribuições dos Estudos Culturais para o campo da Educação: as noções de que identidades são produzidas em múltiplas e variadas instâncias do social e da cultura e de que os meios de comunicação, em particular (e a mídia em geral), se constituem como um locus 
expressivo dessa produção, nas sociedades contemporâneas. Estas noções remetem educadores e educadoras para o conceito de pedagogias culturais, o qual implica 0 reconhecimento e a problematização da importância educacional e cultural da imagem, das novas tecnologias da informação, enfim, da relação entre escolarização e cultura da mídia nos processos de organização das relações sociais e na produção das subjetividades. Remetem também para um importante deslocamento no âmbito da teorização educacional, que desvincula e projeta o currículo para além da escola, e isso impõe uma reconceptualização das próprias noções de escola, de currículo, de conhecimento escolar válido, do ser professor e do ser aluno...

A segunda parte do livro, intitulada Las sexualidades en la escuela, se fixa, como referem os próprios autores, "com minuciosidad y de forma analítica en la producción de las identidades sexuales en este nivel escolar" (p.23). Analisa-se, aí, com base em diários de campo e depoimentos de professores/as e estudantes, não apenas o currículo sexual formal, ou seja, as propostas de educação sexual mas, sobretudo, as culturas sexuais de docentes e estudantes, que atravessam e constituem a dinâmica escolar, em especial no que se refere aos mecanismos e às estratégias de controle, resistência e disciplinarização que aí se efetivam. O objetivo desta análise é entender, fundamentalmente, como é vivida e, por extensão, como poderia ser vivida a escolarização por docentes e estudantes gays e lésbicas. Isso, na perspectiva da autora e do autor, permite pensar em como "se relacionan sus experiencias com las estruturas más generales de la desiguald y, en particular, sobre la forma en que la heterosexualidad obligatoria es una matriz organizativa destas" (p. 113). Em síntese, trata-se, para eles, de buscar compreender as complexas e múltiplas facetas dos processos pelos quais sexualidade e escola se interferem mutuamente.

Em seu conjunto, esta abordagem das relações entre sexualidade e escolarização pode ser bastante promissora para aqueles e aquelas que, no Brasil, se envolvem com esta discussão, em um contexto onde todos se movimentam com muitas cautelas e grandes receios. Pensar as práticas de orientação ou educação sexual, na escola, ainda está reduzido a um exercício apoiado, muito freqüentemente, em um biologicismo estreito que naturaliza a sexualidade e hierarquiza sujeitos e grupos em função de suas práticas sexuais e cujos objetivos explícitos se vinculam à promoção da saúde reprodutiva e à prevenção de gravidez na adolescência e de DST/AIDS. Nessa perspectiva, Debbie Epstein e Richard Johnson, quando descrevem mecanismos e estratégias que permitem entender como a sexualidade é social e culturalmente produzida, em meio a múltiplas e complexas relações de poder que envolvem e conformam os processos de escolarização, nos possibilitam, com o seu estudo, repensar a nossa prática e construir outras abordagens para essas e muitas outras questões.

Enfim, um livro que vale a pena ser lido por educadoras/es e pesquisadoras/es que desejam exercitar aquilo que Foucault ${ }^{3}$ chamou de separar-se de si mesmo: separar-se, para olhar de fora, como se não as conhecêssemos, teorias e práticas que nos constituem tão profundamente que nem as percebemos mais como aprendidas, ou ainda, como sugere a metáfora freqüentemente empregada por estudiosos culturais, incorporar o olhar estrangeiro que, por ser estrangeiro, ainda é capaz de exercitar o estranhamento, a perplexidade e a descoberta diante do próprio saber/fazer...

1 PAIXÃO, S. P. O prazer da aprendizagem. In: LISPECTOR, C. Uma aprendizagem ou O livro dos prazeres. 17. ed. Rio de Janeiro: Francisco Alves, 1990. p. 5.

${ }^{2}$ MEYER, D. Identidades traduzidas: cultura e docência teuto-brasileiro-evangélica no Rio Grande do Sul. Santa Cruz do Sul/RS: EDUNISC; Sinodal, 2000.

${ }^{3}$ FOUCAULT, Michel. História da sexualidade: o uso dos prazeres. 8. ed. Rio de Janeiro: Graal, 1998.

DAGMAR ESTERMANN MEYER 


\section{Um olhar feminino sobre o anarquismo? ${ }^{1}$}

\section{Entre a história e a liberdade: Luce Fabbri e o anarquismo contemporâneo}

RAGO, Margareth.

São Paulo: UNESP, 2001. 368 p.

Historiadora conhecida do público brasileiro, Margareth Rago tem publicado trabalhos que focalizam a História das Mulheres e das Relações de Gênero, dentro de uma perspectiva foucaultiana e anarquista. Neste seu último livro, Entre a História e a Liberdade: Luce Fabbri e o anarquismo contemporâneo, a autora utiliza eses mesmos referenciais para analisar a vida e a obra de uma intelectual anarquista: Luce Fabbri.

Através de uma escrita ágil e atraente, a autora conta-nos, em 341 páginas, os 92 anos de vida desta pensadora italiana. A maneira como mistura a história da vida privada com a obra intelectual da anarquista leva o leitor a se enternecer, a amar e a viver, juntamente com a autora, as experiências de vida e reflexões de Luce Fabbri.

A partir das análises de autores como Michel Foucault e Hannah Arendt, a autora compara a vivência, os ditos e os escritos de Luce Fabbri, mesmo que, por vezes, a própria luce não se reconheça - como a autora destaca - nestas análises, aproximações e comparações que faz da obra da anarquista italiana com a destes autores.

Passado e presente entrecruzam-se nesta obra. O resultado não é uma biografia, mas o desenho de uma vida, construída como obra de arte. Neste desenho, o pensamento anarquista constitui a paisagem: o suporte é a memória. Esta é, o tempo todo, tematizada e questionada.

O livro divide-se em cinco capítulos, os quais reproduzem um percurso temporal: do nascimento e da vida em Bolonha (Itália) à adolescência e à juventude vividas em diversos pontos do país. Simultaneamente, ficamos conhecendo o momento em que Luce descobriuse anarquista e o cotidiano do surgimento do fascismo na ltália. Este é um dos pontos fortes da obra. As tensões do surgimento do fascismo são vividas "por dentro", e a narrativa de Luce é instigante nesta parte.

A fuga da Itália e o exílio no Uruguai é um outro momento forte do trabalho, no qual se misturam emoções, história política e análise teórica. A autora prende, aí, o leitor, envolvendoo nas tramas de uma história quase épica. $O$ Uruguai, descrito por Luce como lugar de liberdade e acolhida, é pintado com as cores da admiração, quase no limite da idealização, especialmente quando se refere ao presidente que governava este país àquela época: José Batlle \& Ordoñez.

Dois outros personagens, além de Luce, são muito focalizados na obra - certamente pela força da narradora: o pai de Luce, Luigi Fabbri, e o anarquista Errico Malatesta. A obra destes é discutida em meio à narrativa das lutas na ltália, da fuga da família Fabbri, passando antes por Genebra e Paris e, finalmente, indo para o exílio na América do Sul.

Outro ponto de destaque da obra é a narrativa da Guerra Civil Espanhola, vivida por Luce a partir do exílio no Uruguai. Esta guerra é pensada como uma rica experiência anarquista. A leitura que Luce faz, morando na América, através das informações que chegam pelos jornais, panfletos, cartas, informantes, é impressionante. A Espanha desse tempo foi, para Luce e para os demais anarquistas da época, "uma grande esperança que se abre no horizonte e, repentinamente, uma enorme frustação".

Naqueles anos, Luce e os companheiros pareciam ver, aí, todos os ideais anarquistas se concretizarem: "vivemos mais na Espanha do que aqui". Eles organizaram comitês de ajuda, divulgaram informações, atuaram em várias frentes de propaganda. Muitos partiram para lutar. Depois veio a dolorosa derrota pela falange franquista. Luce salienta, especialmente, os companheiros anarquistas mortos pelos comunistas.

No balanço que o livro faz sobre o anarquismo, são dissecadas as várias tendências que o formam, os debates, as discussões do momento atual e do passado. São muito ricas as análises que a autora apresenta da obra da 
intelectual anarquista. O socialismo libertário é apresentado como a única utopia que "não foi derrotada, no campo teórico, pelos acontecimentos".

O anarquismo de Luce dá continuidade ao de Errico Malatesta; porém, diferente deste, considera importantes as contribuições trazidas pelo conhecimento científico sobre o homem e a sociedade. Para Luce, "a idéia de liberdade se amplia à medida que progride a ciência, a qual produz uma liberdade sempre maior".

Desconsiderando as tendências anárquicas que partem de leis históricas, ou que constroem utopias e, ainda, as que negam o mundo presente, Luce afirma que a anarquia não tem um programa delimitado, é uma concepção. Mais do que "um ponto bem fixo, ao qual se deva chegar", a anarquia é "um caminho a seguir". Luce critica todo irracionalismo considerado como predomínio do instinto sobre a razão e, conseqüentemente, opressão dos semelhantes, pois, de acordo com ela, os homens têm o instinto do poder. Critica também os anarquistas terroristas, os "expropriadores individualistas, considerando-os danosos para o movimento libertário como um todo. A vida de Luce mostra que $\mathrm{O}$ anarquismo pode ser praticado de diferentes maneiras. A autora mostra como a pensadora constrói sua própria vida - espaço de atuação pública e privada - como uma experiência anarquista. Assim, antes de uma luta política, trata-se "de uma questão ética, que envolve a produção da subjetividade". Neste sentido, o caminho é mais importante do que a finalidade.

Na narrativa de Luce, as reflexões sobre o socialismo, a linguagem, a cultura, a liberdade têm um peso maior do que a narrativa da vida privada: a cronologia é marcada pela vida política. É assim que, entremeando estas discussões, ficamos sabendo de seu casamento, do nascimento da filha, da morte do pai e da mãe, do marido. A autora argumenta que não encontrou, em Luce, o sentimento burguês de intimidade, e atribui isso à sua timidez em falar do privado.

Esta obra traz, assim, um retrospecto muito importante do anarquismo contemporâneo; mostra que não é possível pensá-lo sem as contribuições de Luce Fabbri, mesmo que a autora, por vezes, demonstre um grande fascínio pela pensadora e afirme estar oferecendo um "olhar feminino" sobre o anarquismo. No Brasil e na América Latina, a história do anarquismo tem sido contada à luz das experiências masculinas. É, então, o envolvimento das mulheres que torna o passado singular.

Luce apresenta uma narrativa estruturada racionalmente, muito mais pública do que privada, e reconhece ter tido dificuldades, até 1933, de aceitar as lutas feministas consideradas por ela como coisas da burguesia. $\mathrm{Na}$ época das entrevistas que concedeu à autora, ao referir-se às mulheres, dizia que elas "podem revolucionar o mundo se não imitarem os homens, já que são portadoras de uma cultura própria, de outras formas de percepção, de organização e de elaboração prática, estética e mental".

Negando que isso possa ser resultado de uma essência biológica, diz que, até os dias atuais, a maneira como homens e mulheres são construídos diferenciadamente torna as mulheres inexperientes para serem guerreiras, comandantes e generais, no entanto muito mais aptas para organizar a vida social. Esta posição, defendida também pela autora, aproxima-se daquela reivindicada pelo "feminismo da diferença", que, entretanto, a própria narrativa da vida da pensadora anarquista parece negar. Luce não viveu, em sua época, os constrangimentos de seu gênero. Teve acesso a lugares fechados para as mulheres comuns e foi poupada - pela mãe e, depois, pelo marido das tarefas domésticas comumente atribuídas às mulheres. Talvez por isso não reconheça - e isto é explicitado no livro - que o fato de ser uma mulher tenha a importância que a autora pretende atribuir-lhe.

São, portanto, provocantes as questões que este livro apresenta: o anarquismo como combate às diferentes formas de autoritarismo; o feminino como uma outra narrativa histórica, e também como uma proposta de organização de vida.

' Esta resenha foi publicada em francês pela revista CLIO - Histoire, Femmes et Sociétes.

JOANA MARIA PEDRO 


\section{Discutindo Identidades: multiplicidades políticas, culturais e de gênero}

\author{
Identidades: estudos de cultura \\ e poder \\ FELDMAN-BIANCO, Bela; CAPINHA, \\ Graça (Orgs.).
}

São Paulo: Hucitec, 2000. 176 p.

A análise das fronteiras das identidades e seus embates dentro de uma produção contemporânea de políticas culturais e das identidades como políticas, tendo por contexto as reconfigurações do capitalismo global e seus embricamentos com política e cultura, são algumas das questões abordadas em Identidades: estudos de cultura e poder. Organizada por Bela Feldman-Bianco e Graça Capinha, esta obra reúne cinco ensaios de autores de Portugal, Estados Unidos e Brasil. Em sua maioria, estes textos foram preparados para apresentação na mesa-redonda "Globalização, Estado e Embates de Identidades", na la Conferência Internacional sobre Identidade Étnica e Relações Raciais da Reunião Bienal da Associação Brasileira de Antropologia, realizada em Salvador em abril de 1996. Foram escolhidas pesquisas sobre "migrações internacionais e/ou raça, que pudessem proporcionar subsídios comparativos para se examinar criticamente: as (re)imaginações de nação numa conjuntura marcada por redefinições do papel dos Estadosnação; a emergência de novas políticas nacionais de exclusão ou inclusão de população desterritorializada; e as negociações, contradições, conflitos e embates de identidade em situações de transnacionalidade."' Apesar de os ensaios reunidos nesta obra não estarem centrados nas identidade de gênero(mesmo trazendo os artigos de Mary Castro, que aborda as identidades no feminismo, e de Ângela Gillian, que a certa altura faz relações entre gênero e etnia), suas discussões abrem-se para as diversas categorias identitárias, permitindo que sejam repensados e relidos velhos pressupostos a partir da noção da redefinição de espaços, não só do
Estado-nação transnacionalizado, mas também dos indivíduos. Nesse sentido, o não-lugar, a política de cotas e a dignidade humana, assim como outros pontos de discussão, são de grande interesse para os estudos feministas e nos permitem repensar as inclusões, e suas paradoxais exclusões, não apenas das identidades étnicas, mas também das identidades ou não-identidades de gênero.

Em "Por uma concepção multicultural de direitos humanos", Boaventura Sousa Santos procura identificar as condições em que os direitos humanos podem ser postos a serviço de uma política progressista e emancipatória. Nesse sentido, nos leva à discussão das tensões dialéticas que atravessam a modernidade ocidental na atualidade. É a partir dessas tensões, entre regulação social e emancipação social, entre Estado e sociedade civil e entre Estadonação e globalização, que Sousa Santos tece um quadro analítico que reforça o potencial de emancipação da política dos direitos humanos, tanto no que se refere à fragmentação política e cultural quanto à globalização. Para tanto, Sousa Santos procura uma especificação sobre o que é, ou como se define, a globalização. Entendendo-a como geralmente centrada numa definição econômica, o autor privilegia, em sua análise, um conceito de globalização voltado para as dimensões sociais, políticas e culturais. Acertadamente, o autor define que o que denominamos "globalização" é, antes de tudo e fundamentalmente, um termo que deve ser usado no plural. O termo "globalizações" define, segundo ele, a multiplicidade de relações sociais que estão envolvidas em todo esse processo. A partir deste ponto, elabora o conceito de que globalização "é o processo pelo qual determinada condição ou entidade local estende a sua influência a todo o globo e, ao fazê-lo, desenvolve a capacidade de designar como local outra condição social ou entidade rival."2 Assim, explica ele, aquilo a que chamamos globalização é sempre a globalização bemsucedida de determinado localismo. Partindo do fato de que o "globalizado" traz em si conceitos hegemônicos de um "vencedor", Sousa Santos procura justificar uma política progressista de 
direitos humanos com âmbito global e legitimidade local. Para tanto, e tendo consciência de que os direitos humanos não são universais como artefato cultural, propõe um diálogo intercultural sobre a dignidade humana. Esse diálogo intercultural dar-se-ia, no entanto, entre diferentes culturas, saberes e universos de sentido. Assim, somente um diálogo intercultural intermediado por uma hermenêutica diatópica levaria a uma concepção mestiça de direitos humanos, organizada como constelação de sentidos locais. Por hermenêutica diatópica, entenda-se a discussão dos pressupostos de dignidade humana em suas diferentes formas culturais, tendo em vista suas carências e lacunas, numa busca do maior preenchimento possível de sentidos do que seria, definiria ou permitiria uma política multicultural de direitos humanos o mais completa, compreendida e aceita possível. Os direitos humanos, dessa forma organizados, fariam sentido em diferentes culturas. Sousa Santos nos leva numa viagem para além dos interesses hegemônicos e dos orgulhos culturais exacerbados. Utópico, seu ensaio tem o mérito de nos levar a pensar as possibilidades de maturidade do conceito de dignidade humana.

Já em "Laços de sangue: os fundamentos raciais do Estado-nação transnacional", Nina Glick Schiller e Georges Fouron nos levam a perceber as configurações políticas que diversos países exportadores de emigrantes estão tomando, revitalizando o nacionalismo diante de uma economia global e redefinindo o conceito de Estado-nação como transnacional. Os autores tomam por exemplo e base de pesquisa o Haiti, onde, segundo eles, o nacionalismo tornou-se uma forma de identidade racial. Assim, como outros Estados exportadores de emigrantes, os haitianos definem a nacionalidade pela descendência e não pela partilha da história política comum, língua, cultura ou território. Nação e raça, num contexto de migração transnacional, acabam definindo a identidade nacional. Esta definição do Haiti como Estado sem fronteiras permite a existência do território haitiano como espaço social que pode-se manter dentro dos limites legais de outros Estados-nação.

Segundo os autores, é por conceberem a nação com base na raça e no sangue que, tanto os emigrantes quanto os que permanecem nos seus países, como os dirigentes políticos dos países exportadores de imigrantes, criam ideologias de um Estado-nação transnacional. Os laços de sangue unem todos os haitianos, sendo constantemente renovados pelas condições que enfrentam dentro e fora do país. Como a identidade se dá nas fronteiras, no embate cultural, a construção social da cor branca nos Estados Unidos, país receptor dos haitianos analisados, reforça e reproduz os conceitos haitianos de raça como nação. Pautar-se no sangue ou na raça para legitimar nacionalismos é, segundo penso, uma postura delicada e desconfortável. Fazer uso de ideologias e conceitos que historicamente foram e são usados como pontos legitimadores de discriminação e preconceito é, no mínimo, colocar-se ao sabor do vento. E se ele soprar para o lado contrário das posições desejadas, poderemos retomar subposições. Além disso, como mostram os autores, os haitianos que vivem nos Estados Unidos acabam não se identificando com outros grupos, pois ser haitiano, acima de tudo, é o que os define.

Para além da raça e do sangue, a etnicidade permite muito mais mobilidade aos indivíduos. E, como sugerem os autores, para podermos reagir à "nova ordem mundial", devemos agir coletivamente, indo além dos limites ditados por sangue ou nação.

Assim como Nina Schiller e George Fouron, Ângela Gillian apresenta uma discussão sobre a atual reconstrução social do conceito de raça no Brasil e nos Estados Unidos, partindo de uma reflexão sobre as formas de erosão do princípio da igualdade resultantes da dinâmica de globalização econômica.

Em seu ensaio "Globalização, identidade e os ataques à igualdade nos Estados Unidos: esboço de uma perspectiva para o Brasil", Gillian aponta que as tensões que atravessam a questão da identidade e, sobretudo, a identidade racial, tanto na sociedade estadunidense quanto na brasileira, têm por sintoma as diferentes reformulações de que tem vindo a ser sujeito o princípio da ação afirmativa na luta política dos anos 90. A ação afirmativa como princípio assenta no Movimento pelos Direitos Cívicos e na Lei dos Direitos Cívicos de 1964 e visava eliminar o desequilíbrio entre os sexos e a discriminação racial no local de trabalho e na escola nos Estados Unidos. Era um instrumento para auxiliar a eliminar os preconceitos raciais, de sexo e contra grupos minoritários em geral. No entanto, o que Gillian demonstra é que a lógica de mercado assumiu o "politicamente correto", deturpando o discurso da luta contra o racismo e a opressão sexual e de classe. Dentro 
de uma política de que "todos são iguais sem distinção", eliminam-se e privatizam-se os programas sociais de ajuda aos pobres ou reorganiza-se a política de cotas nas universidades.

No Brasil, a ação afirmativa é entendida como sistema de cotas impostas, identificadas como discriminação invertida ou, pelos simpatizantes, discriminação positiva. Enquanto nos Estados Unidos a ação afirmativa está quase destruída pelas políticas econômicas que promovem a privatização, no Brasil tem sido proposta pelos setores que apóiam o neoliberalismo. No Brasil, segundo Gillian, esse programa se coloca como um paliativo imperfeito e problemático que é oferecido pelo Estado-nação. Trazendo ao lume as identidades étnicas e suas relações e associações com as identidades de gênero, Ângela Gillian discute a persistência, na atualidade, de conceitos raciais e de classe que exprimem preconceitos e pressupostos de "miscigenação", historicamente ligados, por Gilberto Freyre, à formação racial do Brasil no período colonial. Segundo Ângela Gillian, a narrativa sexual, vista em Gilberto Freyre, persiste no padrão histórico da mistura racial. Assim, definir-se pela pele "morena", "mulata" ou "negra", hoje, traz uma questão de debate sobre militância, subalternidade ou servilismo sexual. Nesse contexto de sexualidade racial hierarquizada, "há uma erotização da desigualdade estrutural entre os homens da elite e as mulheres subalternas que sobrevive". ${ }^{3}$ Considerando historicamente a violência racial e sexual como pináculos de uma cultura social, feitorial e hierárquica, que sobrevive no Brasil, Ângela Gillian nos leva a pensar as formas de se negar a ser "objeto", se negar a ser transformado em "mercadoria descartável", diante das possíveis disputas raciais, étnicas ou de gênero fomentadas por políticas econômicas de mercados globalizados. Segundo ela, o processo de construção da identidade, para negros e mulheres, está na luta pela cidadania plena, no esforço pelo reconhecimento da pluralidade e na legitimação do direito e exercício da liberdade. Tanto no Brasil quanto nos Estados Unidos, há a incapacidade das elites de perceber o racismo na perspectiva daqueles que o sofrem, o que acarreta políticas sociais que aprisionam os indivíduos em malhas restritoras de raça, classe e diferença sexual. Negar as diferenças é, segundo percebo, uma forma de tornar invisíveis e mascarados os preconceitos e discriminações sociais. Políticas que privilegiam essa posição tencionam a supressão do indivíduo, numa lógica de mercado sabotadora de potencialidades pessoais.

Acompanhando as discussões sobre identidades, Graça Capinha, em seu ensaio "A poesia dos emigrantes portugueses no Brasil: ficções críveis no campo da(s) identidade(s)", analisa poemas escritos por emigrantes portugueses no Brasil, procurando as ambigüidades e contradições de identidades que se dão no confronto entre inclusão e exclusão, assimilação e resistência, dominante e dominado, num processo de diferenciação entre o "nós"e o "eles", colonizador e colonizado. Dessa forma, a identidade portuguesa articula-se nas fronteiras étnicas, num espaço materializado pela língua escrita, sob a forma de poemas. Reforçando um passado em comum em detrimento do colonialismo, falando ora de irmandade, ora de identidade luso-brasileira, esses imigrantes tecem estratégias de sobrevivência que os jogam entre o desejo de assimilação e a resistência cultural. Essas diferentes perspectivas variam conforme o "lugar" de onde falam: "tornou-se claro, não só nas referências à questão da discriminação nas entrevistas e poemas, como no número de poetas emigrantes a escrever, que existem diferenças fundamentais entre o tecido étnico de São Paulo, do Rio e de Salvador, e que essas diferenças se fundem com a questão de classe quando se trata de identificar o 'português'”. ${ }^{4}$ Segundo ela, em São Paulo, onde há maior número de outros grupos étnicos europeus, maior é o número de imigrantes portugueses a escrever, e foi precisamente onde mais a questão da discriminação e da resistência se colocou. Já no Rio de Janeiro, Graça Capinha encontrou uma situação que chama de intermediária, pois o tecido social é claramente de descendência portuguesa. Não houve de forma tão explícita, quanto em São Paulo, a referência às discriminações ou à necessidade de resistir. Houve, no entanto, manifestações de um grande sentimento de vergonha. $O$ emigrante sente que a situação econômica atual não faz jus a sua memória de Portugal como centro. Ao mesmo tempo, revela medo de que o "outro", sabendo desta situação, encontre condições de legitimar discriminações de pobreza e ignorância contra ele. Fica facilmente perceptível aqui o espaço étnico enquanto possibilitador de confronto cultural e, conseqüentemente, espaço de 
"formação" de identidades. Na Bahia, entretanto, não há produção poética dos imigrantes portugueses que justifique uma referência. Assim, Graça Capinha estipula que a afirmação da identidade portuguesa, na Bahia, faz-se precisamente pela ausência dessa afirmação. Isso faz sentido quando pensamos que o discurso de identidade não se constrói sozinho, dentro apenas do grupo, pois as identidades definemse nas fronteiras étnicas, no embate cultural entre os grupos. Essas fronteiras não são estáticas e sim dinâmicas, e a dinamicidade é dada pela característica relacional da etnicidade.

Graça Capinha aponta que a construção identitária, quando resultado de interseção entre duas línguas e culturas, será sempre múltipla e plural. Da mesma forma múltiplas e plurais, as falas poéticas dos imigrantes trazem no bojo o que são e o que foram, numa duplicidade identitária entre os dois tempos (passado e presente) e os dois espaços (Portugal e Brasil). Segundo ela, o espaço local é transnacionalizado e é nesse sentido que o passado torna-se presente.

Assim, nesse campo discursivo que é o poema, não se encontra "uma identidade", mas sim mutáveis "configurações identitárias". Logo, em maior ou menor grau, variando conforme o ajustamento ou embate com outros grupos imigrantes e seus posicionamentos dentro do contexto social local, os imigrantes portugueses escreveram sobre suas saudades, medos e esperanças e deixaram entrever os paradoxos e dualidades de suas identidades na terra de imigração.

Como último artigo, temos "Transidentidades no local globalizado. Não-identidades, margens e fronteiras: vozes de mulheres latinas nos E.U.A.", de Mary Garcia Castro. Partindo de trabalhos de escritoras mexicanas, chicanas e porto-riquenhas que moram nos Estados Unidos, Mary Castro em "Transidentidades....."examina espaço de trânsito entre fronteiras identitárias. Através de seu nãolugar, de mulher em mundo de homem, de cor escura em espaço branco, de nação transterritorializada, essas escritoras permitem que se vislumbrem as não-identidades, as transidentidades, margens e fronteiras da identidade. A partir delas, Mary Castro percebe as reconfigurações de identidade na terra de imigração. O ser estrangeiro permite que se repensem, diante do outro e da terra do outro, diferentes representações de raça, nacionalidade, etnicidade e diferença sexual. É nesse sentido que a autora busca "sublinhar quanto à transnacionalidade e ao conceito de estrangeiro - o fato de, na multiplicidade de trânsitos, se vir a selecionar ou reler construtos culturais de experiências nacionais". ${ }^{5}$ As releituras e seleções dariam, segundo a autora, subsídios para lidar com poderes, assimetrias e discriminações. Assim, Mary Castro nos leva numa viagem onde o desejo de "ser" pode prevalecer sobre noções homogeneizadoras de experiências. Crítica, ela fica incomodada com autores que buscam "enquadrar" os indivíduos em padrões de identidade e representação précodificados e já aceitos dentro das noções de "razão" da modernidade. Esses autores, agindo assim, negam os impulsos do desejo e diferentes configurações dos processos de singularização. Negam-se, dessa forma, a ver que as possibilidades de "norte" são muitas, permitindo a existência de maneiras de recusar modos de codificação preestabelecidos. Partindo desse ponto, Mary Castro reflete que, no que se refere às especificidades culturais, conceitos como "cultura global", "cultura mundo" e "cultura mundializada", apesar de úteis para as discussões sobre culturalismo, não dão conta da criatividade de sentidos e singularidades no processo de relações globais, nem das tensões entre identidades impostas em relações de subalternidade ou da angústia do trânsito nas fronteiras e margens, em processos de "desidentidades" ou "não-identidades". Dessa forma, o "não-lugar", percebido como espaço de identidades fronteiriças e/ou marginais, permite a reanálise do "lugar". Dentro desse contexto de possibilidades de subjetivações, identitárias ou não, que escapam do controle enquadrador de uma cultura racional e homogenizadora, essas mulheres latinas sugerem que se repensem os processos de exclusão econômica ou cultural, para impedir que as inclusões sejam sempre seletivas quanto a sujeitos e identidades. Dentro disso, a autora busca fazer reflexões críticas à tendência, em certos movimentos sociais, como o movimento negro e o feminismo, de se fixar em identidades.

O que podemos, por fim, observar no conjunto de Identidades: estudos de cultura e poder é a preocupação com a discussão não só das identidades, seus significados e embates fronteiriços, mas também das desidentidades, os não-lugares, as múltiplas e possíveis formulações de identidades, entre fronteiras de gênero, classe, raça e nação. Tudo isso margeado por um 
contexto de Estados-nação, transnacionais ou não, devidamente hierarquizados no sistema econômico global. No mais, é evidente a preocupação com a dignidade humana em suas multifacetadas possibilidades, e é apontada como uma possível margem de apoio uma política multicultural de direitos humanos. Além disso, esta obra permite que repensemos certos conceitos e políticas sociais criados e sustentados por outras nações dentro de seus contextos de história e cultura, que muitas vezes são importados e ajustados às nossas necessidades, mas não nos explicam nem nos ajudam a explicar nada, pois não se adaptam às nossas especificidades culturais. Identidades... caracteriza-se assim como uma obra que se abre para a discussão dos significados e limites da política identitária, numa postura contra-hegemônica das possibilidades de "ser" na atualidade.
1 FELDMAN-BIANCO, Bela e CAPINHA, Graça (Orgs). Identidades: estudos de cultura e poder. São Paulo: Hucitec, 2000. p. 13.

${ }^{2}$ SANTOS, Boaventura de Sousa. Por uma concepção multicultural de direitos humanos. In: FELDMAN-BIANCO, Bela e CAPINHA, Graça (Orgs). Identidades: estudos de cultura e poder. São Paulo: Hucitec, 2000. p.22

${ }^{3}$ GILLIAN, Ângela. Globalização, identidade e os ataques à igualdade nos Estados Unidos: esboço de uma perspectiva para o Brasil. In: FELDMAN-BIANCO, Bela e CAPINHA, Graça (Orgs). Identidades: estudos de cultura e poder. São Paulo: Hucitec, 2000. p. 97.

${ }^{4}$ CAPINHA, Graça. A poesia dos emigrantes portugueses no Brasil: ficções críveis no campo da(s) identidade(s). In: FELDMAN-BIANCO, Bela e CAPINHA, Graça (Orgs). Identidades: estudos de cultura e poder. São Paulo: Hucitec, 2000. p. 119.

${ }^{5}$ CASTRO, Mary Garcia. Transidentidades no local globalizado. Não-identidades, margens e fronteiras: vozes de mulheres latinas nos E.U.A. In: FELDMAN-BIANCO, Bela e CAPINHA, Graça (Orgs). Identidades: estudos de cultura e poder. São Paulo: Hucitec, 2000. p. 152.

LILIANE EDIRA FERREIRA CARVALHO

\section{Feminismo e psicanálise, ainda...}

\section{Para além do falo: uma crítica a Lacan do ponto de vista da mulher}

BRENNAN, Teresa (Org.).

Rio de Janeiro: Record/Rosa dos Tempos, 1997. (Coleção Gênero, v. 4). $360 \mathrm{p}$.

Inicialmente, ressaltaria a importância da tradução desta coletânea pela Editora Rosa dos Tempos, aproximando-nos de autoras que são pouco traduzidas no Brasil. São textos densos, reveladores dos níveis de aprofundamento teórico que marcam, nos países europeus, as trocas fecundas e não isentas de tensões, entre estudos feministas e psicanálise.

A tradução brasileira do título original da edição inglesa Between Feminism and Psychoanalysis, no entanto, coloca-nos algumas questões. Primeiro, o recurso à categoria mulher nas formas essencializadas que o conceito e os estudos de gênero vêm discutindo e complexificando há pelo menos duas décadas (e a Rosa dos Tempos não esteve alheia a esta ebulição, já que se constituiu neste campo e para ele tem contribuído, trazendo a público numerosas obras). Além disso, a ênfase na oposição entre psicanálise e estudos feministas, com um caráter linear e definitivo, o que os próprios textos desta coletânea se encarregam de desmentir.

Estas questões não são novas. Já haviam ocorrido com a edição, em 1990, do livro da americana Nancy Chodorow, com o título original The Reproduction of Mothering: Psychoanalysis and the Sociology of Gender, traduzido pela Rosa dos Tempos como Psicanálise da Maternidade: uma crítica a Freud a partir da mulher.

Será que este apelo a uma tensão irreconciliável, uma clivagem entre psicanálise e feminismo promove a venda de livros? Penso que, ao contrário, o encontro (tenso e fértil) entre os campos atingiria um público mais amplo de 
feministas ou de psicanalistas que usualmente não estão voltados para as discussões sobre gênero.

Quem é esta "mulher" com um ponto de vista homogêneo que critica Freud (no subtítulo de Chodorow) e Lacan (no desta coletânea), jogando fora a criança com a água do banho? Certamente, para a editora, é brasileira, já que as feministas européias e americanas estão discutindo séria e profundamente os encontros e oposições entre psicanálise e feminismo, há várias décadas, conforme este livro vem demonstrar.

A coletânea teve por base uma série de quinze seminários realizados na Universidade de Cambridge, no King's College e na faculdade de Ciências Sociais e Políticas, entre janeiro e julho de 1987, conforme explicita Teresa Brennan em seu prefácio, acrescentando que as mulheres que os apresentaram, provenientes da Índia, dos Estados Unidos, da França e da própria Inglaterra, identificadas com posições distintas e muitas vezes opostas, eram principalmente teóricas da literatura (apenas duas tendo antecedentes nas ciências sociais). Informando sobre as questões em torno das quais se fizeram os debates, a organizadora dos seminários e da coletânea ressalta como ponto comum entre psicanálise e feminismo, a preocupação com a transformação social.

A introdução do livro, escrita também por Brennan, tem partes distintas. Nas páginas iniciais e no item "Os textos" (p. 27 a 36), em que produz a resenha perfeita da coletânea, ela apresenta os artigos, caracterizando-os de forma sucinta, contextualizando-os nas seis partes que compõem a estrutura do livro, cada uma contendo dois ou três textos articulados em torno dos temas privilegiados nos seminários.

Enfatizando que a psicanálise é uma entidade inteiramente política, a autora ensina que "o livro se refere a quatro questões que ficaram estagnadas no pensamento psicanalítico feminista: o estatuto do 'simbólico' lacaniano, a diferença e o conhecimento sexuais, influência do essencialismo sobre a política feminista e a relação entre a realidade psíquica e o social" (p. 10). Questões cujas reflexões, no seu entender, levam a um impasse por terem sido ignorados seus contextos político ou psicanalítico. É disso que ela vai tratar na outra parte de seu artigo, referenciando-se fortemente nas demais autoras da coletânea.

Estes encontros ocorreram na Inglaterra, país que acolheu Freud, quando precisou sair da
Áustria invadida pelos nazistas, o país de Ernest Jones, seu biógrafo, de Robert Strachey, tradutor, comentador e editor de sua obra em inglês, língua a partir da qual ela se difundiu para inúmeras outras línguas. País de Melanie Klein, cuja contribuição à teoria e à clínica psicanalíticas foi de extrema importância e levantou temas fundamentais para as teorias feministas, nas discussões sobre a fase préedipiana e a ênfase no papel da relação mãefilho no desenvolvimento emocional da criança.

Os seminários se realizaram em diálogo com psicanalistas feministas da França, país de Jacques Lacan, o teórico do retorno a Freud pela releitura de sua obra à luz dos avanços da ciência lingüística, e cuja contribuição à teoria e à prática psicanalíticas tem sido responsável pelo diálogo da psicanálise com os paradigmas e movimentos das últimas décadas e da virada do século.

Destes seminários emergem as figuras de psicanalistas cujas teorizações se fazem no encontro entre psicanálise e feminismo. A importância da edição desta coletânea está justamente aí, onde se discutem e aprofundam os olhares sobre as obras de autoras, como as francesas, pouco traduzidas entre nós, pelo menos nos textos que dialogam com o feminismo (o caso de Júlia Kristeva, por exemplo). Assim, os seminários destacam as contribuições de Luce Irigaray, que deles também participou, de Hélène Cisoux e Júlia Kristeva, pela França, de Juliet Mitchell e Jacqueline Rose pela Inglaterra. Se as francesas se destacam por sua oposição a Lacan, quando se trata de pensar sobre a feminilidade em relação ao significante fálico, Mitchell e Rose destacam as contribuições da psicanálise freudo-lacaniana ao pensamento feminista (não contra ele).

As autoras que participaram dos seminários discutiram especialmente as contribuições de uma nova geração de psicanalistas, póslacanianas, às teorias feministas. Foi lembrada também a americana Nancy Chodorow, naturalmente a mais conhecida entre nós, via influência dos Estados Unidos sobre nosso sistema acadêmico, a partir dos anos 60. Acredito, no entanto, que a articulista Toril Moi conseguiu definir bem a importância relativa de Chodorow com respeito à psicanálise kleiniana das relações de objeto, com a qual ela costuma ser identificada, quando a caracterizou como mais próxima das psicologias do ego americanas, versões da psicanálise que Lacan coloca fora do campo freudiano, na medida em que minimizam a concepção de inconsciente.

ESTUDOS FEMINISTAS $619 \quad 2 / 2001$ 
No primeiro capítulo da coletânea Jane Gallop, professora de língua inglesa na Universidade de Wisconsin, estranha a parceria entre feminismo e psicanálise lacaniana, através da crítica aos escritos psicanalíticos de Juliet Mitchell. Autora, entre outros livros, de Feminism and Psychoanalysis: the daughter's seduction e Reading Lacan, ela esclarece que seu artigo se constitui numa versão revista de Juliet Mitchell e as "ciências humanas", que seria publicado em um volume intitulado Lacan and the Human Sciences.

Gallop traça o percurso de Mitchell, do marxismo a Althusser e deste a Lacan. Comentando vários textos da autora, Gallop ressalta os dilemas com os quais ela se debate: natureza $x$ cultura, humano $x$ biológico. Analisando a forma como Mitchell utiliza o termo histórico adjetivando invariavelmente o simbólico lacaniano, Gallop procura demonstrar que são as questões da autora, como feminista marxista procurando juntar feminismo e psicanálise nos anos 60 , que orientam sua leitura particular de Lacan. Este artigo é de muito interesse, já que Mitchell é uma das psicanalistas feministas traduzidas no Brasil (Interlivros, de Belo Horizonte, 1979, e Campus, Rio de Janeiro, 1988).

O artigo de Rachel Bowlby, autora de livros e conferencista de língua inglesa na Universidade de Essex, refere-se às dificuldades das traduções de teorias. Analisa a difícil relação entre feminismo e psicanálise na Inglaterra como marcada pela reinterpretação, na tradução para o inglês, dos termos com que Freud teorizou a questão da feminilidade, os enigmas e negações do feminino, em especial o repúdio ao feminino.

Bowlby, fazendo analogia com a tríplice encruzilhada que se antepõe entre a menina e a feminilidade, retoma os diferentes termos utilizados por Freud (verwerfen, ablehnen e weisen), traduzidos por Strachey como repúdio, apenas. Fala do repúdio das feministas inglesas à psicanálise, as acusações de parte a parte sobre quem está do lado do masculino (patriarcal) e quem faz o resgate do feminino, repetindo, como numa relação/ruptura amorosa, quem exerce o direito jurídico (masculino) de repudiar o outro (a mulher). Voltando à tradução de Freud, a autora se pergunta qual é realmente o usurpador: Strachey, que, talvez por ingenuidade e não por incompetência, unificou, simplificando e radicalizando, os termos empregados pelo autor, ou Lacan, que, no seu entender, desdobrou os sentidos dos conceitos para além de Freud, reivindicando a releitura do autor?

Nos capítulos seguintes, as autoras tratam de aspectos da história institucional das relações entre feminismo e psicanálise.

Lisa Jardine, autora de vários livros sobre filosofia da ciência e mulher e literatura, professora visitante em Cambridge, fala da aceitação da teoria psicanalítica feminista nas universidades, o que, no entanto, não se fez acompanhar de qualquer alteração nas relações de poder entre homens e mulheres nas administrações institucionais. Ela reflete sobre a autorização das falas femininas e masculinas nas instituições analisando um trecho de Deus e o gozo da mulher, do Livro 20 d'O Seminário de Lacan (p. 99-101, na edição brasileira da Jorge Zahar), em que o autor fala da mulher não toda e sua "juissance" suplementar, "um gozo para além do falo", do qual, por mais que se thes suplique (às psicanalistas mulheres), elas nada têm a dizer.

Jardine contrapõe este discurso de Lacan, que classifica como pedagógico, "o discurso da autoridade, a hierarquia da instituição acadêmica" (p. 93), ao de "Speculum, l'autre femme", de Luce Irigaray, em que esta abandona Lacan e começa a produzir seu modelo teórico de um imaginário feminino alternativo. A articulista reconhece que este discurso dentro do discurso psicanalítico tem a capacidade de nele se introduzir para desancorar o discurso masculino da teoria, deslocando seu falocentrismo. Neste sentido, é um discurso político, desestabilizador. A autora, no entanto, refere-se ao desconforto que ele causou a ela e a muitas feministas, pela reintrodução de partes do corpo feminino no discurso, quando o corpo tem sido tradicionalmente identificado pelo feminismo como o lugar da opressão das mulheres.

Alice Jardine, professora de línguas e literaturas românicas na Universidade de Harvard, autora e editora de livros sobre feminismo, reflete sobre a psicanálise na universidade e, em sua condição de feminista ensinando na academia, sobre a prática de duas gerações de professoras, explícita e politicamente feministas, na instituição acadêmica (as doutoradas entre 1968 e 1978 e as doutoradas após 1978). Comparando-as com as primeiras psicanalistas, ela analisa o percurso percorrido pelas mulheres, da voz à escrita, do privado ao público, estabelecendo analogia destes com o fetichismo e a paranóia. 
A autora compara as duas gerações de feministas psicanalistas da academia às três gerações de psicanalistas referidas por Júlia Kristeva em Les temps des femmes. Enquanto as primeiras gerações de feministas e psicanalistas acadêmicas combinavam sedução e resistência aos discursos feminista e psicanalista, as segundas gerações pareciam fazer plena transferência com os dois discursos. Enquanto as primeiras gerações se enquadravam na categoria de mulheres que postulavam um lugar na história linear, ou daquelas que afirmavam um tempo diferente para as mulheres, fora da história dos homens, as mulheres da segunda geração lutavam por um lugar na história masculina, apenas para afirmar suas diferenças singulares e radicais, procurando confundir público e privado. Ela acredita que, cruzando as gerações, as mulheres feministas possam livrar-se da paranóia e seus públicos, do fetichismo e seus privados e, ainda, do próprio conceito de geração.

Iniciando as partes da coletânea intituladas "Por outro simbólico", as primeiras autoras discutem "A coisa essencial". Rosi Braidotti, professora de estudos da mulher na Universidade de Utrecht, chama a atenção para o conceito de diferença que tem ocupado a agenda ocidental desde Nietzsche e Freud, minando a concepção de sujeito conhecedor, derivada do homem da razão. Ela se refere à psicanálise como teoria que representa a mudança histórica que abre a modernidade para a crise da visão clássica do sujeito e para a proliferação das imagens do outro como signo da diferença. Analisa psicanálise e feminismo nos seus encontros e discordâncias, refletindo sobre as concepções de sujeito, diferença, identidade, subjetividade, sexo, gênero.

Considerando mulher e feminismo como metáforas privilegiadas da diferença e da crise dos valores racionais masculinos, Braidotti idealiza uma ontologia feminista, em que as mulheres se responsabilizem por todas as definições que têm sido feitas sobre a mulher como essência histórica (p. 140). A autora retoma a questão do corpo e do essencialismo, reportando-se a Irigaray e seu projeto de um simbólico feminino. Tomando o essencialismo como uma diferença e afirmando que "a mulher teórica feminista que está interessada em pensar sobre a diferença sexual e o feminismo hoje não pode se dar ao luxo de não ser uma essencialista" (p. 128), ela se posiciona por um outro essencialismo, que não abra mão do jogo de representação da mulher, ou da ligação entre o simbólico, ou discursivo e o corporal, ou material (p. 140).

Margaret Whitford, conferencista sobre língua francesa no Queen Mary College, em Londres, autora e editora de livros sobre filosofia e feminismo, propõe uma releitura de Luce Irigaray. Analisando as críticas e leituras da feminista psicanalista francesa por feministas radicais e feministas psicanalistas de língua inglesa, a autora argumenta que estas não dão conta da complexidade das concepções da francesa. Whitford sintetiza as críticas a ela em dois grandes grupos: o primeiro ressalta que Irigaray é uma essencialista biológica que proclama uma feminilidade constituída pela biologia; o outro grupo é formado pelas críticas de psicanalistas lacanianas que a acusam de essencialista psíquica, que distorce as implicações da teoria de Lacan.

A articulista ressalta a erudição filosófica dos escritos de Irigaray, o que em certas circunstâncias tem alimentado as críticas contra ela, procurando esclarecer em que consiste seu projeto. Analisa diferentes textos da autora para contra-argumentar com seus críticos de língua inglesa. Whitford afirma que a escrita de Irigaray, jamais simples ou livre de contradições, contribui para os entendimentos distorcidos de suas idéias. Contra as leituras que considera equivocadas da autora, ela ressalta que a reafirmação da diferença anterior ao Édipo entre homens e mulheres, a recuperação da centralidade da relação mãe/filha como base da diferença, não torna Irigaray uma essencialista biológica linear. Whitford entende que a argumentação da autora, quando caracteriza a relação mãe/filha como não simbolizada, é uma argumentação construída sobre o simbólico, postulando por um simbólico feminino e um imaginário feminino. Lembra que Irigaray não é uma pré-lacaniana, mas uma pós-lacaniana que se confronta com as implicações da obra de Lacan, ressaltando que a ordem simbólica está amarrada a uma estrutura metafísica masculina, fundada num imaginário masculino, que precisaria ser subvertida.

Pelos argumentos de Whitford sobre ela, pode-se entender que o projeto de Irigaray se desenvolve no sentido de buscar um significante feminino que represente a mulher na ordem do simbólico. Exatamente o que sugere Lacan com o axioma "A mulher não existe", ressaltando que não há um significante simbólico que represente 
a mulher, já que ela se diferencia, como o homem, em torno do significante masculino, o falo.

Luce Irigaray, psicanalista praticante, pesquisadora e autora de muitos livros, foi a feminista francesa convidada para os seminários que resultaram nesta coletânea. Seu artigo procura recuperar a importância do gesto na cena psicanalítica, obliterada pela importância atribuída à linguagem verbal. Voltando à famosa cena do fort-da, analisada por Freud (e revista por Lacan, por Derrida), em que seu neto Ernest, brincando com um carretel preso a uma linha, procura lidar com a ausência da mãe, acompanhando os gestos de lançar e puxar o carretel com os sons fort-da (longe-perto, lá-ici em francês), Irigaray reflete sobre estes sons, suas diferenças no alemão e no francês, onde se produzem na boca, no palato, onde se prendem ou se soltam - nos lábios, atrás dos dentes, os sons que se projetam, aqueles que se incorporam. Retoma a significação dos gestos de mãos e braços de Ernest para lançar e trazer de volta seu carretel e procura diferenciar os gestos de meninos e meninas diante da ausência da mãe. Ressalta o fato de que Ernest era menino para argumentar que a criança do fort-da não poderia ser uma menina.

Relembrando gestos femininos na análise e em análises de meninas, a autora descreve possibilidades gestuais de as meninas lidarem com a ausência da mãe (sem o controle do objeto externo) e postula uma diferenciação sexual anterior ao Édipo, que se revelaria em outros sons, em cantilenas com os lábios fechados, e outros gestos, circulares, centrados em si. Na parte final de seu artigo Irigaray compara Dora e Schreber, "o casal das origens da prática analítica" (p. 184), seus gestos, movimentos, palavras, para defender sua concepção de uma diferença sexual desde sempre - sua concepção de que a criança psicanalítica não é neutra, diante de uma diferenciação que se irá produzir em um momento estruturante posterior.

Nos capítulos seguintes, com subtítulo "Para além do falo", temos mais três autoras. Elizabeth Wright, conferencista e visitante de língua alemã em Cambridge, analisa a relação entre feminismo e psicanálise concentrando-se na crítica feminista, para a qual a questão fundamental é como dar à mulher acesso ao discurso: através da submissão à linguagem pública do patriarcado, ou pela criação de uma outra linguagem, que não alcança hegemonia, mantendo-se às margens, estranhada. Wright defende a construção de um espaço para a mulher entre estas fronteiras, no contexto pósmoderno.

Ressaltando estar, em sua investigação crítica da psicanálise, do feminismo e do pósmodernismo, "interessada em revelar os fundamentos incertos de qualquer sistema idealista que se considere baseado em dados ontológicos" (p. 190), Wright sustenta que a crítica feminista oferece a instância mais clara e visível das dificuldades de tentar subverter ou reformar, a partir de dentro, qualquer sistema. Assinala, no entanto, a importância, para a pesquisa crítica, de poder manter-se aberta a tal subversão. A autora ressalta que a crítica literária, que enfrentou a ortodoxia na instituição psicanalíica, foi o campo onde floresceu a psicanálise-pelofeminismo, tornando a psicanálise mais política do que já era para algumas feministas. A crítica literária deu às mulheres acesso ao discurso como escritoras e como críticas, o que elas não haviam logrado obter na psicanálise ou na política. Wright destaca, na relação entre psicanálise e gênero, o fato de esta ter oferecido ao feminismo os instrumentos conceituais para demonstrar que o gênero é simbólico e não biológico, ao mesmo tempo em que, paradoxalmente, construía a mulher em torno do símbolo fálico. Afirmando dever-se à teoria e à prática do lapso de linguagem causado pelo desejo inconsciente o fato de as feministas continuarem a abraçar Freud e Lacan, a articulista discute algumas críticas de feministas inglesas a Lacan. Através da leitura de Toril Moi, ela retoma Júlia Kristeva, centrando-se na questão pré-edipiana da relação da criança com a mãe e na escritura desta relação. Cita Suleiman, que, apontando para o fato de as mães serem escritas, ao invés de escreverem, solicita mais informações das próprias mães, através de diários, ensaios, etc., instando-as a falarem sobre si e suas relações com os filhos, desconstruindo assim, talvez, o arcabouço patriarcal que harmoniza a mulher com este lugar-tarefa da maternagem.

Wright discute o percurso do feminismo que, adotando a psicanálise, encampa o pósmodernismo, ambos interessados em estender fronteiras para além das oposições binárias. Discutindo a intersecção entre feminismo e pósmodernismo, o primeiro oferecendo ao segundo 
uma política aos campos literário e artístico, Wright procura destacar as principais linhas do debate sobre o pós-modernismo, desde diferentes posições, que analisa pela referência a vários autores/as. Ela reflete também sobre o rompimento das fronteiras dos discursos, comentando a prática de uma escrita pósfeminista de escritoras influenciadas por Lacan, como Kristeva e Hélène Cisoux. Ressaltando que "o feminismo examina os processos pelos quais se concede, ou se recusa, $O$ acesso da mulher ao discurso, e ao mesmo tempo inaugura um novo modo de pensar, escrever, falar" (p. 201) e as críticas feministas oferecem, junto com leituras subversivas de textos tradicionais e modernos, um contínuo desafio às estruturas de poder dominantes com suas alegações de imparcialidade, a autora destaca que não há nada de imparcial sob o sol, nem o próprio discurso feminista, que prospera com suas diferenças internas (e por elas).

O artigo escrito por Morag Schiach, conferencista sobre língua inglesa no Queen Mary College, autora de livros, um dos quais sobre Hélène Cisoux, tem como título uma citação desta autora, tirada de seu texto "A risada da Medusa": "O 'simbólico' deles existe, detém poder - nós, as semeadoras da desordem, o conhecemos bem demais".

Schiach analisa a obra de Cisoux, de quem é tradutora para o inglês. Em seu entender, os escritos desta autora permitem "analisar o que definimos como teoria feminista ou crítica feminista e considerar as implicações de uma prática teórica que começa com uma política articulada" (p. 205) já que o feminismo é um termo político, um questionamento do poder e da possibilidade de mudança. Para Schiach, recorrendo aos termos da psicanálise, Cisoux está constantemente minando-os. O simbólico é descrito como o simbólico "deles", um conceito do qual as mulheres deveriam distanciar-se, na possibilidade de articularem um novo simbólico, "nosso". Para a autora, Cisoux equacionou o poder com o simbólico, equação que nem todos aceitariam, mas fundamental para a escrita da francesa, para quem "a organização da linguagem, os duplos conjuntos hierarquizados de oposição que estruturam o pensamento filosófico e a linguagem narrativa, é o que produz o fundamento lógico para, e os meios de, oprimir a mulher" (p. 207). Poder ao qual ela antepõe a possibilidade de recusa e desordem. Analisando vários textos de Cisoux, Schiach procura mostrar de que modo e até que ponto a autora interroga os conhecimentos que estruturam as identidades e as relações sociais femininas. Em sua opinião, até os excessos de Cisoux, que se encontram e são perpetuados nos textos filosóficos e de ficção, devem ser compreendidos como parte de seu compromisso de minar as representações da "mulher".

O argumento de Schiach é que os textos em que a autora francesa analisa a obra de Clarice Lispector, como também suas peças de teatro, não devem ser lidos somente como parte da construção de uma estética feminina, mas devem ser colocados no contexto de um conjunto de problemas teóricos sobre a natureza da diferença (questão melhor articulada, segundo Schiach, na obra de Derrida). Tomando o gênero como um termo estruturante, na opressão oficial e simbólica, Cisoux tenta desenvolver uma prática de escrita para as e em benefício das mulheres, já que é na escrita que ela vislumbra a possibilidade de transformação.

No último capítulo destas considerações "Por um outro simbólico", Naomi Segal, professora de línguas modernas no St. John's College, Cambridge, autora de livros sobre filosofia, literatura e psicanálise, parte da interpretação do mito de Narciso centrando-se na figura e no papel de Eco na narrativa, para analisar algumas obras do récit confessional francês dos séculos XVIII e XIX. Todos textos escritos por homens, sobre homens e, por implicação, segundo a autora, para homens.

Segal ressalta como uma das semelhanças entre os textos, na narrativa da vida fracassada do protagonista, o fato de a mulher central, um tanto mais velha que ele, servir de foco às temáticas da morte da mãe no parto e do desejo incestuoso. Narrativas em que as mulheres são faladas pelos homens (narradores, protagonistas, leitores) e lhes servem de espelho. Narrativas em que, para que eles possam emergir ao simbólico do pai, elas precisam ser abandonadas e mortas. De acordo com Segal, "essa manobra coloca em cena uma epistemofilia na qual o conhecimento dele é buscado a expensas do dela" (p. 230). É este o destino da maioria das mulheres nos récits analisados. Mas, mortas as mulheres, os protagonistas ficam sem o eco, o espelho que os sustenta e os torna visíveis para si próprios. Para a autora, a morte dos homens em conseqüência de seu narcisismo aponta para uma alternativa, 
uma leitura própria de mulheres, uma comunicação entre mulheres, segundo uma outra epistemologia.

A quinta parte da coletânea, intitulada "Razão e revolução", é composta por dois artigos. No primeiro, Toril Moi, residindo na Inglaterra e lecionando literatura na Noruega e nos Estados Unidos, autora e editora de livros sobre feminismo e literatura, escreve sobre "Pensamento patriarcal e a pulsão do conhecimento". Analisa a produção de autoras como Evelyn Fox Keller e Susan Bordo, em suas críticas a Descartes e à filosofia e humanidades em geral. Keller classifica a ciência como uma ideologia que divide o mundo em duas partes, a que conhece (mente) e a que é conhecida (natureza), dividindo sujeito e objeto e atribuindo gêneros às partes dicotomizadas. Segundo T. Moi, Keller se fundamenta nas idéias de Chodorow sobre o desenvolvimento das estruturas da personalidade masculina e feminina para refletir sobre a ciência masculina. Apontando esta inspiração comum entre Keller e Bordo, a autora as coloca, com Chodorow e Gilligan, como "expoentes de uma variedade psicossocial do feminismo da diferença" (p. 256), denunciando, em suas posições, um essencialismo ao contrário culturalista.

Comentando os escritos de Michelle le Doeuff sobre conhecimento, feminismo e feminilidade, destaca a crítica desta autora à filosofia (ciência masculina) que, paradoxalmente, busca a completude, achando possível construir uma estrutura sem falhas, quando o fator que a possibilita é a falta - o que falta ser pensado. Ciência patriarcal que circula a mulher como duplamente faltante: em relação ao falo e em relação ao conhecimento. A falta da mulher como falta errada, sendo sempre a de um homem e não a falta de conhecimento, condição para a filosofia, tornando-a incapaz, assim, de filosofar, de pensar racionalmente. $O$ pensamento racional como emblema da autosuficiência narcísica masculina. A mulher como símbolo da falta e da negatividade fundamentando a própria filosofia ocidental - 0 irracional, fora do discurso da razão, é o que na verdade o confirma, por contraste. A feminilidade como a sombra, o excluído, o inimigo interno que opera dentro da filosofia, como suporte da racionalidade.

Le Doeuff fala da importância de uma ciência aberta, inacabada, capaz de refletir sobre sua própria relação com a exclusão, na medida em que possa abandonar qualquer aspiração de lograr a um fechamento mágico, imaginário. Esta autora relaciona o método clínico de análise com uma nova forma de conhecimento, que estabelece uma relação diferente entre sujeito e objeto, não simplesmente invertendo a relação, mas subvertendo-a, ligando os dois pólos, tornando-os dependentes na situação de análise, introduzindo aí um novo termo - o inconsciente que, como Lacan ressalta, não está só do lado do analisando, mas também do analista, um ponto de encontro lingüístico, significativo, que circula.

Para superar a separação entre razão e emoção, em que incorre a própria Keller quando critica, através de Descartes, a filosofia ocidental, Toi utiliza a concepção freudiana de epistemofilia, ou pulsão do conhecimento, como possibilidade de resposta ao feminismo, no sentido em que desloca os dualismos razão/ emoção, mente/corpo. Argumenta que, usando esta concepção, Freud destaca a implicação do corpo, da sexualidade, em qualquer atividade humana e na própria sublimação. Conforme explicita, Toi pensa que uma filosofia da ciência feminista e antiessencialista tem mais a ganhar com Freud e Lacan do que com as psicologias do ego americanas (p. 273).

Gayatri C. Spivak, autora de livros e artigos sobre feminismo, desconstrução e crítica ao imperialismo, professora de língua inglesa na Universidade de Pittsburgh, é uma célebre tradutora de Derrida para o inglês. $O$ artigo de Spivak inicia pelo comentário da introdução do livro de Jacqueline Rose Sexuality in the Field of Vision, em que esta rejeita Derrida como um certo tipo de essencialista subjetivista. Spivak se percebe como defendendo um tipo de Derrida contra Rose defendendo um tipo de Lacan. A questão tratada por Spivak, segundo suas palavras, não é que a desconstrução não consiga fundar uma política, enquanto outros modelos de pensamento o conseguem, mas 0 fato de a desconstrução contribuir para denunciar os problemas implícitos dos programas políticos, ao torná-los mais visíveis. "Agir não é, portanto, ignorar a desconstrução, mas sim transgredi-la ativamente sem dela abrir mão" ( $p$. 277). Com este propósito, a autora se detém na questão do nome mulher na filosofia de Nietzsche, através da análise de Derrida e na concepção elaborada por este de différance.

A respeito do sujeito feminino nos escritos de Rose, Spivak procura marcar a distinção entre 
epistemologia/ontologia, de um lado, e axiologia, do outro, o que a seu ver está confundido nas críticas de Rose ao sujeito descentrado de Derrida. Discutindo várias formas de nomear mulher no projeto político do feminismo (e pensando sobre as mulheres que se sentem excluídas das nomeações/representações feministas), a autora aponta para a esperança, por trás da vontade política, de que a própria possibilidade do nome possa ser finalmente apagada.

Joan Copjec, editora de revista em Nova York, autora de artigos e livro sobre feminismo, psicanálise e cinema, inaugura a última parte da coletânea, ainda referida à "Diferença sexual", que trata do "Psíquico no social". Preocupada com a questão do real, que considera subsumida nas análises contemporâneas da relação entre psicanálise e política, sua tese é a de que "o real é o que une o psíquico ao social", e esta relação é governada pela pulsão de morte (p. 305).

Baseia-se nos escritos de Freud O Mal Estar na Civilização e Para Além do Princípio do Prazer para elaborar suas reflexões sobre o princípio da realidade e o social, o princípio do prazer, as pulsões de vida e morte. Compara escritos de Freud e Bergson, de Bergson e Lacan. Analisa a questão da causa, pela referência a Lacan e Aristóteles, chegando à questão do sujeito e do sujeito do feminismo. No interesse de evitar a eliminação da realidade psíquica ou da realidade social nas análises, ela afirma que o conceito de causa precisa ser recuperado e repensado no sentido de possibilitar a compreensão da relação entre a ordem social e a existência psíquica, especialmente para a análise feminista, que depende da existência de uma semi-independência psíquica em relação às estruturas patriarcais.

Parveen Adams, conferencista sobre psicanálise de Brunel, co-fundadora e co-editora da publicação feminista $m / f$, escreve um ensaio sobre o lesbianismo sado-masoquista, diferenciando-o do masoquismo clínico, caracterizado como patológico.

De acordo com ela, no sentido de centrarse fora da ordem do social e familiar e recusando as formas de patologia feminina organizadas dentro do campo fálico, a lésbica sadomasoquista resolve seu problema de entrada no desejo sem qualquer coisa que possa ser caracterizada como gozo feminino. Como uma sexualidade transgressora que só pode associarse a uma realidade psíquica numa relação complexa com alguma porção muito nova da realidade externa, o lesbianismo sadomasoquista consegue lograr, segundo a autora, a separação radical entre gênero e sexo.

Como se pode perceber, esta é uma coletânea de muito interesse, tanto para os estudos de gênero quanto para outras áreas, como a crítica literária e a psicanálise. Traz discussões densas, atuais, com enfoques variados, que não caberiam "no ponto de vista da mulher", sugerido no subtítulo da edição brasileira. Ela mostra justamente o oposto: a riqueza e diversidade de concepções de mulheres reunidas para discutirem suas reflexões em torno de temas relevantes para os estudos feministas e de gênero.

MARA COELHO DE SOUZA LAGO 


\section{Mulheres em Santa Catarina: com quantos modos de faz uma História?}

\author{
História das mulheres de Santa \\ Catarina.
}

MORGA, Antonio (Org.).

Florianópolis: Letras Contemporâneas; Chapecó: Argos, 2001. 285 p.

Os onze trabalhos que compõem História das mulheres em Santa Catarina são parte de um movimento historiográfico mais amplo, em que os modos de pensar e viver das mulheres, seus sentimentos, lutas e ações passaram a ser abordados e analisados em sua historicidade. Faz parte de uma História que assumiu a intersecção de variados e múltiplos ritmos de tempo, diversificando e ampliando as suas possibilidades interpretativas. Ao fazê-lo, foi construindo diferentes caminhos analíticos e denotando uma acurada preocupação em propor suportes teóricos e metodológicos, que propiciassem resultados em que a visibilidade da ação das mulheres também pudesse ultrapassar o momento em que se pautava por uma narrativa simplesmente descritiva. Assim, tais estudos visaram a compreender e explicar a experiência feminina em contextos específicos, sem descuidar de sua coerência e compromisso com o adensamento dos referenciais teóricos envolvidos na análise. Movidas por essas preocupações, vemos desfiar-se as diversas tematizações e problematizações que os vários autores deste livro propuseram para as 'mulheres de Santa Catarina'. É nesse sentido que se procura dar a conhecer as suas formas de expressão e manifestação em variadas dimensões sócioculturais e espaciais. São parteiras, professoras, estudantes, jornalistas, prostitutas, mineiras, agricultoras, donas-de-casa etc. Vivem no campo e/ou na cidade ou vilas, nas casas, nas ruas, festas, minas, salões e casebres; realizam travessias entre o campo e a cidade e por oceanos, interligando espaços e culturas distantes. A compreensão de como viveram e do que fizeram de suas vidas é buscada, em grande parte dos artigos, através do trabalho com a memória e do uso de relatos orais. Em muitos casos, também se recorre aos escritos mais íntimos, como cadernos pessoais e de recordação, à imprensa e aos processos judiciais, isto é, aos possíveis lugares em que possam ser encontrados os registros de todos aqueles que sempre viveram à margem da História e, até há pouco, também às margens das preocupações dos historiadores.

Em "Personagens à beira de um porto: mulheres de Itajai", Marlene de Fáveri apresenta o conjunto de mulheres que compunham aquela cidade portuária, as quais, convivendo com as idealizações e expectativas que eram construídas para as suas vidas, experimentaram, de forma diversa, os desafios presentes em sua cotidianeidade. Às representações da doçura, do comportamento exemplar e da boa dona-decasa, segundo o ideal proposto para a mulher alemã e mais abastada, a autora não apenas contrapõe a coexistência de outras identidades étnicas, como as contrasta com a presença das mulheres pobres e/ou às margens de tal modelo: comerciantes, solteironas, meretrizes, lavadeiras, doceiras, vendedoras ambulantes, mendigas, loucas etc. Perscrutando arquivos de jornais, escritos memorialísticos e contos, a autora analisa como essas mulheres produziram práticas reveladoras de um esforço de autonomia e resistência, diante das injunções sócio-culturais a que estiveram submetidas.

São outras, porém, as configurações de classe, etnia e gênero que implicam a conformação das experiências, das lutas e formas de resistência das mulheres que são abordadas por Carlos Renato Carola, em "As trabalhadoras das minas de carvão de Santa Catarina". O cotidiano do trabalho dessas mulheres, que ultrapassa os limites da casa e do labor doméstico, é enfatizado em sua dimensão política: trata-se das relações de poder e dos modos de sociabilidade experimentados pelas mulheres mineiras em seu espaço de trabalho. As múltiplas faces de suas ações diante dos conflitos e dos processos de controle e exploração a que foram submetidas são discutidas pelo autor, que as remete à 
diversidade de funções e às diferentes formas de reação diante da diversidade de funções e trabalhos que exerceram, inclusive aqueles extremamente "pesados". Tanto as brigas, suspensões, desobediências e faltas, como a obediência, conversas, risos, músicas e brincadeiras são vistas como interfaces de um mesmo processo, em que dominação e resistência se engendram mutuamente. Nesse sentido, as mulheres não são interpretadas simplesmente como vítimas, mas, sim, como atores sociais de jogos que permitem um questionamento e recusa dos discursos que afirmam a docilidade, a fragilidade e a submissão femininas, legitimando e sustentando as hierarquias de gênero.

Janine Gomes da Silva, em "Lugares do recôndito, espaços de sociabilidade: história das mulheres imigrantes de Joinville", destaca como as vivências cotidianas de mulheres que compuseram a elite germânica que emigrou para a cidade de Joinville, a partir de 1851 , foram permeadas pelas tensões entre brasileiros, alemães e demais grupos étnicos, num processo em que a cultura do grupo dominante procurou se impor sobre a cidade, constituindo espaços de sociabilidade restritos e excludentes dos demais grupos. É compondo e constituindo esse cenário que se podem entender as ações e formas de sociabilidade de várias mulheres alemãs. Além de indicar as suas diferentes trajetórias sociais e espaciais, Silva discute como muitas delas construíram o seu presente, em novas terras, a partir da reconstrução dos laços de sociabilidade, que se sustentaram em práticas de suas próprias memórias. Estas se encontravam expressas em velhos álbuns de recordações, que traziam registrados os laços de amizade que precisaram deixar nos lugares por onde passaram, seja na Europa, seja no Brasil. Entrecruzando desejos de felicidade, de fé e bondade com evocações de saudades e de recordação, tais álbuns podem ser considerados como elementos emblemáticos do modo como ressignificaram as suas tradições, estabelecendo vínculos entre o passado e o presente.

Com outro enfoque, Arlene Renk, em "Mulheres camponesas: experiências de geração", procura reconhecer o modo como a memória e a cultura operam os vínculos entre passado e presente, ao tratar das variações nas experiências sociais em torno de trajetórias espaciais e culturais na vida de camponesas, descendentes de imigrantes alemães, italianos e poloneses, no oeste catarinense. É bastante interessante o modo como a autora relaciona as mudanças geracionais e, especialmente, de faixa etária com a forma como as colonas perceberam e sentiram as transformações no mundo rural e os seus deslocamentos físicos por outros espaços e territórios. Sem se descuidar das diferenças étnicas e culturais dessas mulheres, Arlene Renk faz uma análise que acompanha um processo, permeado por tensões, em que a autoridade paterna e limites étnicos e confessionais restringiam qualquer possibilidade de autodeterminação feminina. Ao acompanhar o deslocamento dessas camponesas para o mundo urbano, a autora redimensiona e temporaliza o processo de "encolhimento do mundo rural" e de redefinição das fronteiras entre cidade e campo. Os significados das mudanças nas formas de sociabilidade e das mobilidades sociais, espaciais, econômicas e culturais são reinterpretados sob a perspectiva das reavaliações que as mulheres fizeram de seus percursos de vida e dos sonhos, desejos, expectativas e práticas que expressaram, sob a perspectiva de uma outra geração e faixa etária. Através do estudo de várias trajetórias individuais de vida, vemos emergirem individualidades que rompem, mesmo que de forma relativa, com as rígidas relações familiares e comunitárias anteriormente vividas. Nesse processo, as mulheres passam a ganhar visibilidade política, deslocando-se por novos espaços e assumindo novos papéis em movimentos sociais, cooperativas, sindicatos, partidos políticos, associações filantrópicas e religiosas e, mesmo, na Assembléia Legislativa. Além disso, ao mesmo tempo em que a velhice é percebida em sua imposição de limites, pois algumas se referem ao corpo como "estragado" e "carroça velha", em seus enunciados também transparece uma grande satisfação, aliada a um sentimento de maior liberdade, em poder, agora, "viver a vida". Nesse sentido, é fundamental o valor que atribuem aos recursos da aposentadoria, a qual ainda permite o tempo livre e a possibilidade de viver outros espaços de sociabilidade a que antes não tinham acesso: bailes, viagens em excursões etc.

A reconstrução dos modos de vida e de socialização de mulheres imigrantes teutobrasileiras da Colônia Blumenau é também objeto dos estudos de Cristina Scheibe Wolf, em "Como se forma uma "boa dona de casa": a educação de mulheres teuto-brasileiras na Colônia

ESTUDOS FEMINISTAS $627 \quad 2 / 2001$ 
Blumenau (1850-1900)". Utilizando-se de jornais, cartas e memórias, a autora nos apresenta uma análise atenta e rigorosa, sob a forma de um texto extremamente prazeroso de ser lido, em que logo sinaliza para o papel fundamental que era atribuído às mulheres na reconstituição e organização social da vida dos imigrantes. Assim, no processo em que estes procuraram forjar uma identidade étnica teuto-brasileira, é que foram reafirmando as suas expectativas e idealizações acerca de um certo modelo de mulher. Para isso, contrapuseram a imagem da mulher brasileira "fútil, ociosa e desleixada" à da mulher alemã "boa dona-de casa, ordeira e trabalhadora". Sem perder de vista as formas diferenciadas e conflituosas em que ocorriam esses processos de socialização - mediados pelas intersecções entre gênero, classe e local de moradia -, a autora também procura reconstituir toda a sua complexidade, considerando o embricamento entre os diversos modos e lugares em que se realizam: nos âmbitos familiares, religiosos e escolares. Os valores morais e os hábitos de conduta da "boa dona-de casa" são aqui analisados tendo em vista uma certa "cultura do trabalho" que foi sendo constituída/reconstituída em torno de determinadas necessidades, interesses e sentimentos. Estes eram marcados pelos valores da solidariedade, generosidade $e$ afetividade, oriundos de um estilo de vida tradicional, que se mesclavam àqueles preconizados pelos reformadores religiosos católicos e protestantes: diligência, ordem, economia etc.

Buscando trilhas que permitam conhecer os processos em que se constituíram as subjetividades de mulheres que viveram em um outro tempo e lugar, Maria Teresa Santos Cunha procura compreender as "Práticas de leitura entre professores primários (1950-1960)" em Florianópolis. Aqui, tais práticas são entendidas enquanto uma das estratégias que formaram as sensibilidades, o gosto e os sentimentos, constituindo visões de mundo e modelando condutas, normas e valores que deveriam compor o "ser mulher". Porém, o processo de leitura também é percebido em uma outra dimensão, qual seja, enquanto uma prática criadora de sentidos múltiplos e singulares, o que implica a compreensão de que os assentimentos e/ou dissentimentos costumam ser experimentados de forma contraditória, pois se encontram sempre referidos às vivências particulares que cada sujeito experimenta.
Através de um trabalho criterioso e revelador de uma fina acuidade e sensibilidade, a autora percorreu um caminho em que levantou os acervos das bibliotecas escolares, a circulação e veiculação de livros pelos jornais e chegou às estratégias que foram desenvolvidas para a apropriação do lido, através não somente de testemunhos pessoais das leitoras, como também dos registros manuscritos de suas impressões sobre as leitura, feitas durante o período em que se formavam professoras.

Se o romance, tipo de literatura chamada "cor-de-rosa" e aprovada pela Igreja Católica, foi reconhecido por esta autora como o principal tipo de leitura realizada por leitoras de meados do século XX, em Florianópolis, é neste mesmo lugar, mas em outro tempo, que Antonio Morga, em "Espaços de visibilidade feminina: Nossa Senhora do Desterro no século XIX", também identifica a literatura romântica e o drama como divulgadores de uma pedagogia das condutas que visou a um controle sobre as formas de sociabilidade e as práticas afetivas das mulheres. Contudo, ambos os autores remetem a temporalidades históricas e a enfoques teóricos e metodológicos distintos. Morga se refere a literatura, música e peças teatrais, veiculadas pelos romances, pela imprensa, por sociedades dramáticas e por diversos manuais para orientar o contato entre homens e mulheres e para manter os códigos de sedução dentro das normas de sociabilidade preconizadas. Procura identificar os discursos do e sobre o teatro e as diversas formas de expressão do romantismo, incluindo os sentimentos que suscita o "compartilhamento das lágrimas", com o discurso médico-higienista e com as distinções sociais que a burguesia em ascensão busca produzir, ao normatizar formas de requinte e modos de comportamento diante de si e do outro.

Por outro lado, ao encontrar registros de práticas sociais de mulheres, naquele período, depara com figuras diversificadas e contraditórias. Os viajantes descreviam a polidez, urbanidade, luxo no trajar-se e boas maneiras da mulher desterrense. A imprensa, grande veiculadora, em tons românticos, de modelos para a conduta feminina, opunha as figuras da mulher esposa, filha e mãe às da namoradeira, sedutora e vaidosa; além disso, também se referia, de forma anônima, aos casos daquelas desviantes da norma. Em seu texto, para além de objetivar ou conseguir definir um determinado perfil para as mulheres de elite de Desterro - 
comparando suas práticas com as clivagens sociais que sofreram suas condutas e subjetividades - o autor conseguiu conferir àquele contexto histórico determinado um olhar sobre o modo como a construção daquela dada sociedade e de seus laços de sociabilidade foi também permeado pelas preocupações que as práticas e comportamentos de mulheres suscitavam. Além disso, tal estudo também permite dar maior visibilidade às formas como as mulheres fizeram parte dos processos sob os quais as relações de poder e as tensões sociais emergiram.

É também sobre Florianópolis, entre os períodos estudados por Cunha e Morga, que se debruçou o olhar de Karla Leonora Dahse Nunes. Procurou reconstituir, em "Antonieta de Barros: uma história", o campo sócio-cultural determinado em que se inscreveram as ações dessa personagem e, ao mesmo tempo, analisar as suas possibilidades, mesmo que relativas, de ação autônoma especialmente na condição de jornalista, em que foi modelada e também ajudou a modelar formas de agir. Não se descuida, portanto, do fato de que as suas ações estiveram determinadas pelos limites de um tempo - trata-se da década de 1930 - em que ganhavam relevância os padrões de exigência estética conferidos à modernidade e onde se manifestava o "desejo de controle político de gestos, olhares, lugares, sabores, comportamentos, padrões". Porém, o que se destaca neste estudo é o modo particular com que "Maria da llha" (pseudônimo de Antonieta) denotou uma percepção e sensibilidade crítica e contundente sobre vários dos fatores que implicavam a submissão e exclusão das mulheres. Nunes faz notar a maneira como a experiência e as condições específicas de vida de uma mulher negra e provinda de uma classe social menos privilegiada, que foi professora, jornalista e chegou a ser deputada estadual, marcaram as formas com que expressou os seus modos de ver e sentir as questões de seu tempo.

Carmen Suzana Tornquist, com "A mão e a luva: processo de medicalização do parto e o corpo feminino em Florianópolis", e Karen Cristina Réchia, com "Das senhoras dos "repolhos" e das "roças": ou de como nasciam os bebês", tematizam os saberes das mulheres e das parteiras em torno da prática do parto e a rede de sociabilidades, as esferas de poder e prestígio que se constituíam em torno desse fato. Ambas se referem a um período quase similar, que se estende até a década de 1950-1960 e às cidades de Florianópolis e Treze de Maio, respectivamente. O modo como significam a importância e o sentido dos relatos orais, dos quais se servem para a pesquisa, determina os rumos dos conhecimentos que produzem. Para compreender os elementos que compunham a cultura e o contexto histórico de que tais práticas fizeram parte, Réchia procurou distinguir o que era recorrente nas lembranças das parteiras, a forma como elas se lembravam e como atribuíam significações para a gravidez, para os rituais em torno do parto, para o resguardo e para o "ser parteira". Também atribuindo grande importância para o modo como as mulheres lembram, Torquinst chama a atenção para a "performance narrativa" presente nos testemunhos de mulheres não letradas que estiveram envolvidas com tais práticas: parteiras, parturientes, filhas de parteiras. Tanto quanto o discurso verbal, o discurso corporal que o acompanha é um elemento essencial na interpretação operada pelo pesquisador. Os saberes e poderes femininos relativos aos cuidados com o corpo, a saúde e as crianças são entendidos como constituídos e constituintes de uma dada experiência e cultura. Denotam uma prática de trabalho que é atravessada por outras categorias de valor: necessidades de sobrevivência, solidariedade, prestígio e autonomia. Revelam territórios de maior liberdade de deslocamento espacial das mulheres, relativizam territórios de poder, prestígio e autoridade em sociedades onde as diferenças e hierarquias de gênero, classe e etnia são bastante demarcadas. Os trabalhos, por fim, abordam o estabelecimento do discurso médicocientífico e a medicalização das parteiras, processo que, segundo Tornquist, faz irromper ao lado dos saberes, anteriormente compartilhados, uma multiplicidade de práticas que "rompem com a idéia de irmandade/unicidade entre as mulheres", revelando "nuances bastante complexas nas interfaces entre gênero, classe e profissionalização".

Em seu conjunto, todos os textos deste livro que puderam recorrer ao uso do trabalho com a memória, visando a reencontrar as experiências de personagens femininas escondidas pelo tempo e desconhecidas pelas caminhos da pesquisa historiográfica, também se preocuparam em situar/explicar as implicações metodológicas da opção por tal caminho. É o caso do empenho rigoroso de 
Maria Bernadete Ramos Flores, em "Trabalho da memória/memória do trabalho/trabalho e festa". Ao mesmo tempo em que a autora vai explicando e tecendo os fios das lembranças sobre festas que as mulheres do interior da llha de Santa Catarina relataram, também as vai referindo aos valores, crenças e experiências que foram forjadas no cotidiano de suas experiências coletivas de vida. Assim, entrelaçam-se história do cotidiano e história e memória de mulheres, reconstituindo-se um cotidiano politizado e complexo, que ultrapassa os limites do doméstico e do interior da casa e em que se entrosam o lúdico, o trabalho e o religioso. Desta perspectiva, observam-se processos sociais antes não visíveis e que revelam múltiplas e diversificadas vivências, as quais, por sua vez, denotam o caráter histórico do entrecruzamento de temporalidades e espacialidades múltiplas.

História das mulheres em Santa Catarina demonstra o esforço em redimensionar e particularizar os objetos da produção historiográfica brasileira e, ao mesmo tempo, revela um esforço rumo à necessidade de descentralizar os tradicionais pólos de divulgação da produção científica no país. Com a apresentação dos diversos enfoques, problematizações e rumos das pequisas dos diversos trabalhos, contidos neste livro, nesta resenha, puderam ser indicados os diversos caminhos de pesquisa que permitem descontruir estereotipias de gênero e, ao mesmo tempo, compreender a ação das mulheres como engendrada, também, pelas suas origens nacionais e étnicas, pelas suas relações de classe e trabalho, religiosas, geracionais, etárias etc. Tais caminhos e resultados de investigação possibilitam, portanto, romper com categorias abstratas e idealidades universais, como as de "condição feminina" ou "cultura feminina". Vemos emergir experiências múltiplas e contraditórias realizadas na trama de um cotidiano complexo e politizado, sempre remetido a conjunturas concretas e provisórias. Ao se atribuir visibilidade e explicação à ação das mulheres, redimensiona-se a compreensão dos processos sócio-históricos, ao mesmo tempo em que as teorias e metodologias que dão suporte ao fazer historiográfico são também revistas, redimensionadas e ressignificadas.

MARIA DE FÁTIMA SALUM MOREIRA

\section{Traduzindo identidades}

\section{Identidades traduzidas: cultura e docência teuto-brasileiro- evangélica no Rio Grande do Sul}

MEYER, Dagmar Elisabeth Estermann

Santa Cruz do Sul: EDUNISC; São Leopoldo: Editora Sinodal, 2000. 242 p.

Mobilizando um invejável e alentado confortos do distanciamento" (p. 8), a pesquisa teve uma história que aponta a inserção da autora, Dagmar, em três contextos bem distintos e definidos: uma família de imigrantes alemães, um Grupo de Estudos e Pesquisas em Educação e Gênero (GEERGE) e a docência na Faculdade de Educação (FACED/UFRGS). Estas pertinências, muito bem tramadas, não caíram em qualquer tom confessional mas evidenciaram, sim, que as investigações são sempre interessadas, uma vez que elas se desenvolvem em torno de questionamentos feitos por alguém que começa e consegue formular determinadas perguntas a partir de um lugar e em um tempo específico.

Os dados, além de sustentarem análises engenhosas, são discutidos quanto à procedência, fidedignidade, modo de coletar e de usar, ou seja, ela discute como chegou aos dados e como estes chegaram ao livro, sem descuidar em nenhum momento da elegância da escrita: justa escolha das palavras, frases ordenadas, controle dos parágrafos, o que só vem assegurar, mais uma vez, a qualidade do estilo em que o texto é construído. 
A opção por desnaturalizar/desconstruir idéias e conceitos já arraigados, os ditos "lugarescomuns", foi realizada com pleno êxito, sempre historicizados, isto é, sempre colocados na ordem do histórico, portanto, do mutável, como se encontra na passagem descrita à página 38: "Os imigrantes alemães não compunham, então, um grupo homogêneo, sob muitos aspectos: eram oriundos de diferentes Estados e regiões, muitos eram camponeses e servos, outros tantos marginalizados urbanos, alguns podiam ser intelectuais em exílio político". De igual maneira, a passagem que se encontra à página 115 quando a autora reafirma "a impossibilidade de se falar, no contexto sócio-histórico alemão, acerca da escola, da formação de professores e professoras ou do exercício do magistério no singular, o que, por extensão, mina também a idéia de uma concepção homogênea e amplamente compartilhada de escolarização que passaria a ser apresentada como sendo uma característica (ou tradição cultural) desses imigrantes no Brasil".

Essas citações remetem, igualmente, à questão do método utilizado. Ele foi construído/ tramado a partir de uma salutar e bem-sucedida abertura epistemológica (anunciada à página 28) que the deu legitimidade, abandonando corajosamente o modelo dogmático e, por vezes, ortodoxo ainda presentes em certos setores da pesquisa em Educação, em que as situações já estão definidas por antecipação, cabendo às/ aos estudiosas/estudiosos apenas comprová-las. Ao invés disso, a profundidade sem afetação, a flexibilidade interpretativa e os diálogos fecundos com os campos de Estudos Culturais e Estudos Feministas mostraram a História e suas formações discursivas como uma representação do passado que caminha através do relacional das disputas, das hipóteses em confronto, sem a ansiedade cartesiana de causa e efeito encadeados em uma seqüência fatal de conclusões.
Detetivescamente, como convém a uma pesquisadora, a autora perseguiu evidências, pistas, e esta perseguição foi realizada por ações relacionais e diversificadas, sistematizadas ao longo do livro e expressas por ações como "selecionei", "organizei dados", "analisei", "reorganizei a pesquisa", "fui induzida a buscar", "percorri caminhos investigativos". E foi na totalidade dessas dimensões que, para além das análises que empregam gênero como categoria útil, Dagmar buscou a compreensão dos papéis ou dos destinos de mulheres e homens, humanizando um passado que não foi tão certo e preciso quanto algumas teorias criadas para entendê-lo.

Ao longo dos três capítulos do livro, a autora problematiza as representações em torno de uma cultura teuto-brasileiro-evangélica, mostrando as representações culturais e a produção de identidades culturais; analisa a Escola e a Docência como uma arquitetura de um regime de representação cultural; e aborda, no terceiro capítulo, uma identidade docente entre a tradição e a tradução cultural. Tudo isto apresentado em análises sofisticadas que interligam conceitos como nação, religião, gênero e raça/etnia.

Sem dúvida, um outro grande mérito deste livro reside na sutileza, no detalhamento e no cuidado com que a autora se debruça sobre a questão da cultura, como frisou na Apresentação a professora doutora Guacira Lopes Louro (UFRGS), para quem "as representações de escola e de docência, inscritas no interior de um determinado contexto cultural, são analisadas como resultantes e, ao mesmo tempo, constituidoras desse projeto cultural específico" (p. 9).

Ao final, a certeza de que as Identidades foram traduzidas e revelaram outras possibilidades de puxar o fio da História da Educação, na perspectiva dos Estudos Culturais e Feministas, além, é claro, do barthesiano prazer de ler.

MARIA TERESA SANTOS CUNHA

ESTUDOS FEMINISTAS $631 \quad 2 / 2001$ 


\section{Paternidades e masculinidades em contextos diversos}

Paternidades en América Latina.

\begin{tabular}{l}
\hline Fuller, Norma (Ed.). \\
\hline Lima: Pontificia Universidad Católica del \\
Perú, Fondo Editorial, 2000. 418 p. \\
\hline
\end{tabular}

Tem sido possível pontuar uma mudança de enfoque nos estudos de gênero, particularmente a partir de 1994, pós-Conferência Internacional sobre População e Desevolvimento, no Cairo, e pós-Conferência Mundial sobre a Mulher (Beijing, 1995), que direcionaram sua atenção para a participação masculina e a responsabilidade dos homens nas questões que afetam o cuidado com os filhos e as decisões com relação à reprodução e à sexualidade. Ao se acompanhar o fluxo da produção sobre identidade masculina e paternidade percebe-se que nos anos 90 o tema ganha um fôlego especial, aglutinando boa parte das pesquisas desenvolvidas no campo dos estudos de gênero no Brasil. É também nesse período que o tema da masculinidade aparece com maior ênfase em outros países da América Latina. Até então, nos estudos sobre a vida privada, a fala de mulheres de diferentes camadas sociais era predominante. Sobre a subjetividade masculina pairava um quase silêncio, quebrado apenas por alguns pesquisadores/psicólogos que chamavam a atenção para uma suposta "crise da masculinidade".

A constatação de que muitas demandas colocadas pelo movimento feminista ainda não haviam sido equacionadas redefiniu, por outro lado, uma agenda de pesquisa e intervenção, sobretudo com questões relativas à saúde e aos direitos sexuais e reprodutivos. Não surpreende, portanto, que a década de 1990 tenha como referência um interesse específico pela construção social da masculinidade como objeto de pesquisa, sobretudo entre pesquisadores do campo da saúde reprodutiva e da sexualidade. Ainda que a noção de gênero aponte para o caráter implicitamente relacional do feminino e masculino, até então os estudos de gênero vinham privilegiando pesquisas sobre a condição das mulheres na família, no trabalho, nos diferentes espaços de poder. Os movimentos feminista, gay e lésbico tiveram papel fundamental ao alertar para as desigualdades de gênero, para os direitos sexuais e reprodutivos. A evidência das diferenças de sexo e de como estas diferenças constroem as desigualdades de gênero e as relações de subordinação constitui, portanto, a base para o crescimento de pesquisas focalizando os homens e a construção das masculinidades.

Na América Latina, incluindo o Brasil, o interesse está relacionado, no âmbito mais geral, às mudanças nas relações de gênero e à inadequação dos paradigmas explicativos diante da complexidade da dinâmica social; no âmbito mais restrito, político até, relaciona-se à constatação de que a compreensão das práticas masculinas, por exemplo, pode contribuir para melhorar os resultados de programas voltados para a saúde das crianças, para a prevenção de doenças sexualmente transmissíveis e para as decisões de planejamento familiar. Em parte, essa temática surge como reflexo do desenvolvimento que os estudos feministas e de gênero alcançaram desde a década de 1970 e que demonstravam a necessidade de novas e diferentes estratégias para maior eqüidade entre homens e mulheres, bem como para expressão das sexualidades e culturas sexuais. Os modelos hegemônicos de masculinidade e feminilidade heterossexuais como via única na conformação das identidades sexuais e dos comportamentos são colocados em questionamento.

Este preâmbulo nos ajuda a dimensionar a importância de uma coletânea como Paternidades en América Latina, organizada por Norma Fuller. Os/as autores/as reunidos/as neste livro passam a ser, na atualidade, fonte básica para novos estudos sobre masculinidade $e$ paternidade. Mara Viveros, José Olavarria, Benno de Keijzer, Teresa Valdés, Ondina Fachel Leal e a própria Norma Fuller, entre outros, versam em seus textos sobre o significado que a paternidade tem para os homens, para o seu projeto de vida, 
problematizando as dificuldades que os homens enfrentam e o impacto das transformações conjugais para o exercício da paternidade.

Os artigos resultaram da Conferência Paternidades na América, organizado pelo Departamento de Ciências Sociais da PUC do Peru. Por isso, além dos textos, que permitem uma leitura comparativa das análises e das informações colhidas em pesquisas em diferentes países, é possível acompanhar o debate subjacente à temática, em geral privilégio apenas daqueles que estiveram fisicamente presentes ao evento. $O$ debate assim explicitado acaba contribuindo, juntamente com as pesquisas apresentadas, para o delineamento de metodologias de trabalho e políticas públicas voltadas para a população masculina e para as demandas desta.

Apesar das perspectivas teóricas e analíticas distintas, os textos coincidem ao expressar a paternidade como uma dimensão fundamental na vida dos homens, sejam eles dos segmentos populares, sejam dos médios, para os quais o exercício da paternidade está relacionado a fatores específicos que precisam ser considerados quando se for estudar esse assunto. Entre os fatores que influenciam a construção social da paternidade está a relação familiar (com o pai, com a mãe e depois com a própria mulher ou mãe de seu filho); as condições sociais e econômicas; a relação com o grupo de pares. Também a estrutura sociocultural de uma dada sociedade marca a vida de homens (e de mulheres) e por conseqüência exerce efeito sobre a paternidade, até mesmo na disponibilidade de tempo que os homens têm para se dedicar aos filhos e à família. Algumas tarefas com relação aos filhos e à casa demandam mais tempo do que outras, influenciando a divisão social e sexual do trabalho, da mesma forma que certos valores e costumes estabelecem expectativas com relação à masculinidade e à paternidade.

A paternidade, assim como a maternidade, é um momento de transformação, marcada, sobretudo na sociedade latino-americana, pela assunção da responsabilidade (de prover, de cuidar, de proteger). Essa relação aparece em quase todos os artigos que compõem a coletânea. A precarização do trabalho remunerado entre os homens, por exemplo, tem afetado sobremaneira a identidade masculina, ao colocar em risco o lugar de provedores econômicos do grupo familiar, outro aspecto discutido pelos/as autores/as. Mara Viveros argumenta que as novas exigências das mulheres e as crescentes demandas afetivas dos filhos têm aumentado, em muitos casos, os sentimentos de frustração dos homens, por não conseguirem mais sustentar o ideal de provedores e de modelo paterno para seus filhos. Esses temores podem resultar muitas vezes em situações de violência familiar. Ao ler os relatos descritos nos artigos, percebe-se claramente um questionamento dos homens pesquisados sobre a forma como têm vivenciado a paternidade. Numa atitude claramente reflexiva, esses homens percebem as contradições sobre como têm exercido sua paternidade e nem sempre as expectativas por eles mesmos criadas têm sido alcançadas (Este é outro ponto em comum nos artigos: há um modelo de paternidade ideal que tanto permeia o imaginário social dos homens pesquisados como o dos/as pesquisadores/as.).

O encontro de pesquisadores com diferentes pontos de vista, que adotam procedimentos analíticos e teóricos distintos, como é o caso desta coletânea, resulta num panorama das principais questões ainda em aberto, clamando por serem investigadas. Algumas delas puderam ser pinçadas durante a leitura, tais como o impacto do divórcio e dos pais separados de seus filhos nas relações familiares e de gênero; casais homossexuais e o estabelecimento de relações familiares e de filiação; a jornada de trabalho e as implicações na articulação família/filhos/trabalho, e o efeito disso nas atribuições paternas e maternas; o impacto das novas tecnologias reprodutivas na definição de parentalidade; a equação autoridade/poder relacionada à paternidade e aos novos arranjos familiares; o lugar masculino na saúde reprodutiva e no planejamento familiar, incluindo a decisão por eventual aborto etc. $O$ livro suscita estes e outros temas, mas sobretudo permite cotejar hipóteses para as pesquisas sobre famílias e relações de gênero.

SANDRA UNBEHAUN 


\section{Um roteiro da construção social da "violência de gênero": conflitos interpessoais e judiciarização}

\author{
Violência, gênero e crime no \\ Distrito Federal.
}

SUÁREZ, Mireya e BANDEIRA, Lourdes (Orgs.).

Brasília: Paralelo 15;Editora da Universidade de Brasília, 1999. 536 p.

O livro organizado por Mireya Suárez e Lourdes Bandeira é fruto de um trabalho coletivo no sentido forte do termo. Trata-se da publicação dos resultados de projetos de pesquisa voltados para o estudo das "violências contra as mulheres" e articulados em torno do convênio do Núcleo de Estudos e Pesquisa sobre a Mulher (NEPeM) da Universidade de Brasília com a Secretaria de Segurança Pública do Distrito Federal. É obra de equipe, composta de 12 capítulos assinados por várias pesquisadoras que, sem perder especificidade nem autonomia, mantêm uma interlocução entre si que demonstra a base cooperativa sobre a qual foi realizado o trabalho como um todo. Assim, supera-se a simples justaposição de trabalhos, ampliando-se o alcance dos resultados de cada um isoladamente. O diálogo entre os capítulos é peça fundamental para a realização do tour d'horizon sobre a complexa temática recortada no livro. A meu ver, o mérito primeiro de Violência, gênero e crime no Distrito Federal é o efeito de conjunto, ou melhor, a complementaridade de perspectivas.

Para se ter uma idéia da extensão do campo coberto pela obra, convém destacar que os 12 capítulos estão organizados em quatro partes: "Discursos sobre a violência"; "Narrativa da violência"; "Reflexões teóricas sobre o estupro" e ; "Uma análise dos dados sobre a violência". A primeira parte engloba os seguintes capítulos: "A noção de crime sexual" (Mireya Suárez, Danielli Jatobá França e Renata Weber); "O discurso policial comentado" (Mireya Suárez); "Notícias de violência: uma leitura" (Tânia Montoro); e "Violência contra mulheres na mídia impressa" (Adriana Carvalho Lopes). Na segunda parte: "Pai e avô: o caso de estupro incestuoso do pastor" (Lourdes Bandeira e Tânia Mara Campos de Almeida); "Violência conjugal: os espelhos e as marcas" (Lia Zanotta Machado e Maria Tereza Bossi de Magalhães); "Uma reflexão sobre a casa como lugar de violência inocente" (Tânia Mara Campos de Almeida); e "Retóricas sobre o crime" (Danielli Jatobá França). A terceira parte é composta por: "Sexo, estupro e purificação" (Lia Zanotta Machado); "Violência sexual, imaginário de gênero e narcisismo" (Lourdes Bandeira); e "A estrutura de gênero e a injunção do estupro" (Rita Laura Segato). Na última parte, um capítulo único intitulado "Um recorrido pelas estatísticas da violência" (Lourdes Bandeira). Destaca-se também a interessante introdução assinada por Mireya Suárez e Lourdes Bandeira.

A complexidade do campo em que se situa a obra está marcada pela transversalidade dos fenômenos abordados, bem como pela sua persistência. Ela tem colocado em questão, nos últimos anos, a capacidade analítica dos modelos clássicos e as políticas de intervenção neles baseadas. Nas últimas décadas essa temática tem sido motivo de inquietação em países tão diferentes quanto Estados Unidos da América, França, Canadá ou Brasil, e atravessa, em cada um deles, o conjunto dos seus segmentos sociais. Desse modo, os movimentos sociais que lutam contra a impunidade nos casos de "violência contra mulheres" são, ao mesmo tempo, fenômeno local e global, e os modelos interpretativos e propositivos resultam de complexo amálgama desses dois campos. Há que se considerar ainda que a expressão violência contra a mulher reagrupa toda uma gama de fenômenos, razão pela qual pode ser considerada como um conjunto heterogêneo de experiências sociais. A homogeneização que resulta dessa expressão é problema teórico, mas também tem implicações na definição de políticas sociais de intervenção. 
Os enormes avanços realizados no conhecimento empírico das relações interpessoais, sobretudo no âmbito da conjugalidade e das práticas institucionais correlatas, nos convidam para mais um movimento que deve ser o da dúvida teórica radical. Porém, uma dúvida teórica que envolva a percepção social dos fenômenos estudado e dialogue diretamente com ela. Nesse sentido, entendo que o livro Violência, gênero e crime no Distrito Federal responde a uma demanda, supre uma carência, da maior atualidade para as ciências sociais: uma releitura teórica e empírica da construção social da "violência de gênero" no Brasil.

Na obra cruzam-se discussões teóricas, análise de dados e a construção simbólica da "violência" na mídia, resultando uma visão mais profunda e abrangente dos temas abordados. Assim, temos uma leitura teórica que desloca o centro da análise para fenômenos concretos, afastando-se da homogeneização contida na noção de "violência", o que contribui para desmitificar $o$ alarmismo de um crescente e inelutável aumento da "violência", que, ao invés de nos despertar para a ação, pode inibir nossa capacidade de agir. Neste livro, nos capítulos sobre estupro, incesto e "crimes sexuais", por exemplo, a discussão teórica torna-se mais refinada e abre perspectivas para modelos interpretativos específicos e para o desenvolvimento de ações concretas de prevenção e promoção de políticas públicas alternativas. Seus capítulos se alinham num fluxo comum, compondo um mosaico de questionamentos teóricos em diálogo com a sua base empírica, o que é a segunda, mas igualmente importante, qualidade desta obra.
Uma terceira característica, mais sutil, resulta do cruzamento das duas anteriores: o resgate da polifonia presente nas práticas sociais analisadas pelas pesquisadoras. De fato, ao longo dos 12 capítulos estão presentes as vozes das mulheres, mas também da mídia, dos agressores, além das falas dos policiais e dos discursos dos teóricos. Pode-se afirmar, portanto, que estamos diante de uma obra rara, cuja raridade aponta para uma trajetória, um roteiro de pesquisa, ao mesmo tempo "engajada" como se dizia no jargão militante - e contemporânea, por mostrar cenários em constante remontagem.

As três marcas que pontuaram a minha leitura da obra fazem pensar na importância desse tipo de trabalho, no seu alcance como instrumento para a elaboração de políticas públicas e, sobretudo, na virtude de apresentar as múltiplas trilhas percorridas para a construção social da "violência de gênero". Isso me leva a identificar na obra uma proposta de pesquisa que deve ser seriamente discutida, porque nos permite refletir para além da generalidade do objeto "violência", especificando-se na complexidade dos conflitos interpessoais e na transformação da intimidade, para usar a fórmula consagrada. O que acredito poderá, no limite, refletir-se nas políticas sociais, especialmente no questionamento da posição privilegiada, senão exclusiva, dos processos de judiciarização. Afinal, precisamos de novos modelos interpretativos que nos permitam ultrapassar os limites dos territórios conceituais que mostraram a sua força fazendonos ver a invisibilidade da "violência contra a mulher", mas que agora nos prendem aos seus próprios avanços.

THEOPHILOS RIFIOTIS 